\title{
Pollution Prevention Opportunity Assessment Approach, Training, and Technical Assistance for DOE Contractors
}

\section{FY96 Report, ADS \#ALHQ-334-1A-7}

Federal Manufacturing \& Technologies

$$
\begin{array}{r}
\text { MA1 } 13987 \\
\text { OSTI }
\end{array}
$$

Susan Pemberton

KCP-613-5933

Published March 1997

Approved for public release; distribution is unlimited.
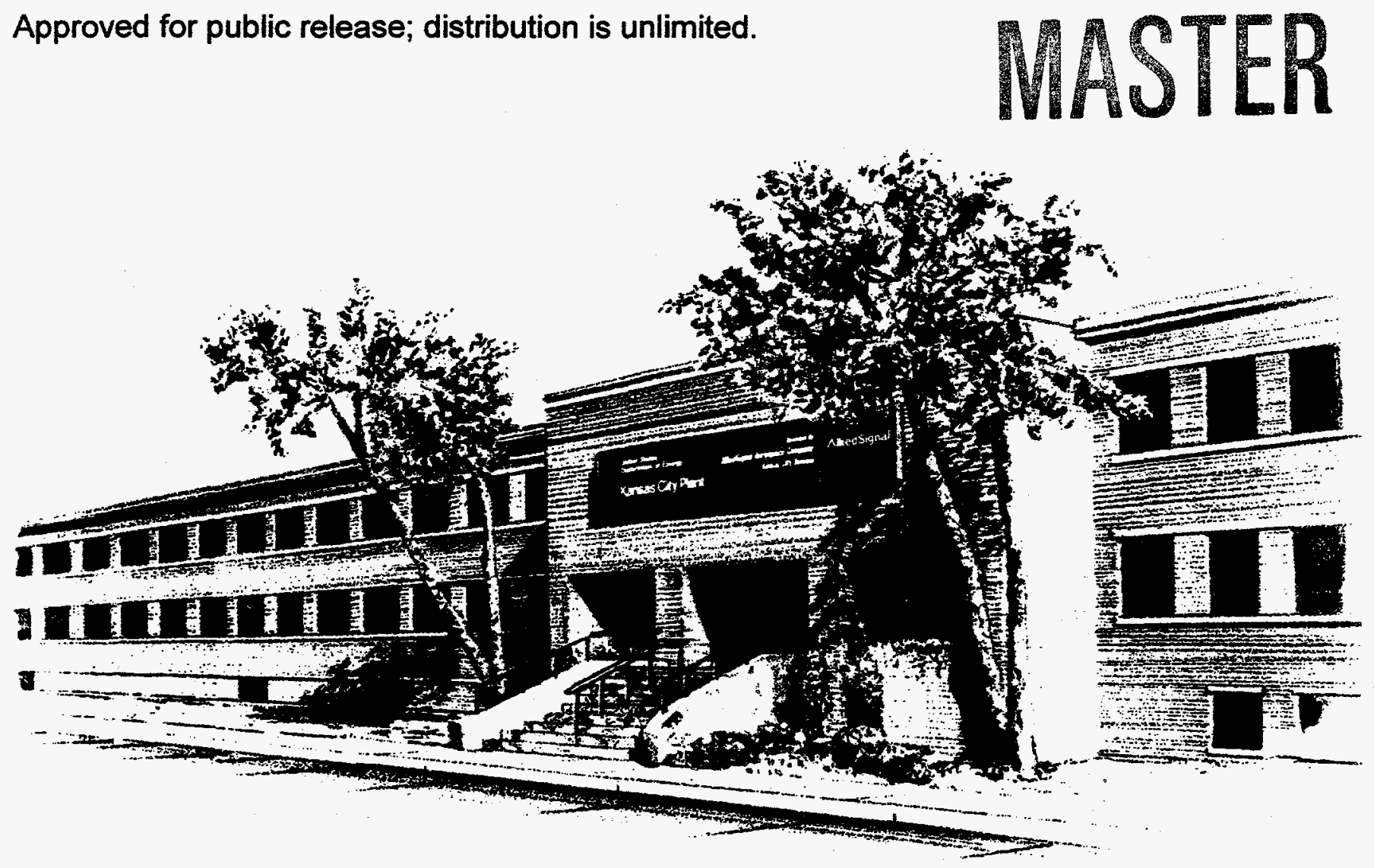


\section{DISCLAIMER}

This report was prepared as an account of work sponsored by an agency of the United States Government. Neither the United States Government nor any agency thereof, nor any of their employees, makes any warranty, express or implied, or assumes any legal liability or responsibility for the accuracy, completeness, or usefulness of any information, apparatus, product, or process disclosed, or represents that its use would not infringe privately owned rights. Reference herein to any specific commercial product, process, or service by trade names, trademark, manufacturer, or otherwise, does not necessarily constitute or imply its endorsement, recommendation, or favoring by the United States Government or any agency thereof. The views and opinions of authors expressed herein do not necessarily state or reflect those of the United States Government or any agency thereof.

Printed in the United States of America.

This report has been reproduced from the best available copy.

Available to DOE and DOE contractors from the Office of Scientific and Technical Information, P. O. Box 62, Oak Ridge, Tennessee 37831; prices available from (615) 576-8401, FTS 626-8401.

Available to the public from the National Technical Information Service, U. S. Department of Commerce, 5285 Port Royal Rd., Springfield, Virginia 22161.

A prime contractor with the United States Department of Energy under Contract Number DE-AC04-76-DP00613.
AlliedSignal Inc. Federal Manufacturing \& Technologies P. O. Box 419159 Kansas City, Missouri 64141-6159 


\section{DISCLAIMER}

This report was prepared as an account of work sponsored by an agency of the United States Government. Neither the United States Government nor any agency thereof, nor any of their employees, make any warranty, express or implied, or assumes any legal liability or responsibility for the accuracy, completeness, or usefulness of any information, apparatus, product, or process disclosed, or represents that its use would not infringe privately owned rights. Reference herein to any specific commercial product, process, or service by trade name, trademark, manufacturer, or otherwise does not necessarily constitute or imply its endorsement, recommendation, or favoring by the United States Government or any agency thereof. The views and opinions of authors expressed herein do not necessarily state or reflect those of the United States Government or any agency thereof. 
DISCLAIMER

Portions of this document may be illegible in electronic image products. Images are produced from the best available original document. 
KCP-613-5933

Distribution Category UC-707

Approved for public release; distribution is unlimited.

POLLUTION PREVENTION OPPORTUNITY ASSESSMENT APPROACH, TRAINING, AND TECHNICAL ASSISTANCE FOR DOE CONTRACTORS

FY96 REPORT, ADS \#ALHQ-334-1A-7

Susan Pemberton

Published March 1997

Susan Pemberton, Principal Investigator

Project Team:

Milt Bryant

Carole Stone

Mike Gerding

Michelle Maurer

Scott Tubbesing

Harrison May

Art VanHook

Charles McField

Don Watson

Bill Parker

Ed Welborn

Bill Schlosberg

Mark Wilson

Sponsored by the United States Department of Energy, Office of Environmental Management, Office of Pollution Prevention, EM-77 


\section{Contents}

Section

Page

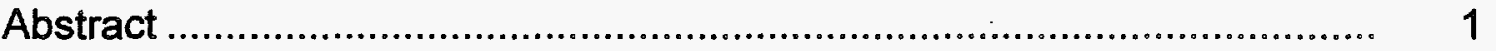

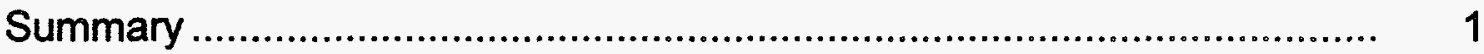

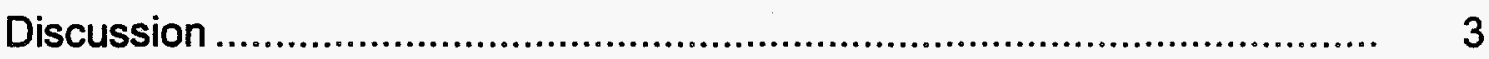

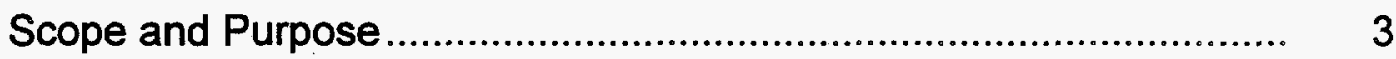

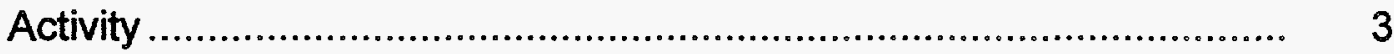

General Background........................................................... 3

Environmental Restoration Training Module ............................ $\quad 5$

PPOA Training and Technical Assistance ................................ 7

Implementation of DOE-Wide Database .................................. 15

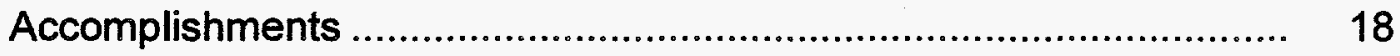

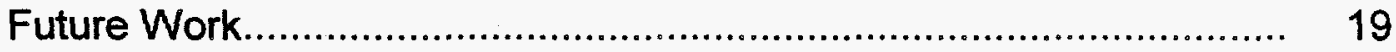

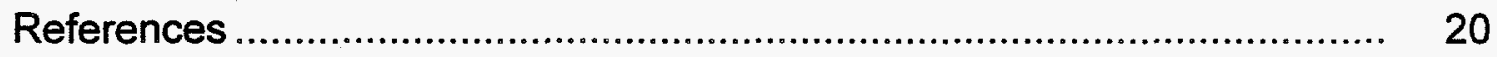

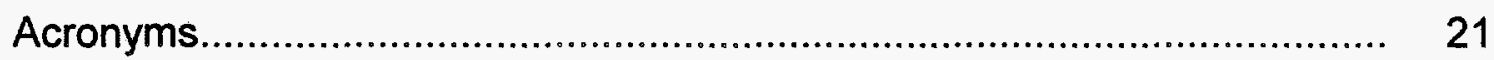

Appendices

A. PPOA-ER Course Outline …............................................... 22

B. ER-P2 Hierarchy Exercise ..................................................... 25

C. PPOA-ER Model Worksheets ….............................................. $\quad 30$ 


\section{Illustrations}

Figure

Page

1 PPOA Training Class Attendees by DOE Operations/Field Office ...... 10

2 PPOA Training Class Attendees by Lead Cognizant Secretarial Office.

3 PPOA Training Class Results - Routine PPOA Course ..................... 14

4 PPOA Training Class Results - ER-Specific PPOA Course .............. 14 


\begin{abstract}
One of the tools used in a successful pollution prevention program is a pollution prevention opportunity assessment (PPOA). PPOAs can be used to identify the nature and amounts of waste and energy usage from processes and projects within a site's operations, identify the opportunities that exist for pollution prevention and energy conservation, and then evaluate those opportunities for feasible implementation. The purpose of this project is to share the Kansas City Plant's (KCP's) PPOA methodology and experience with other DOE personnel and DOE contractors. This consisted of three major activities in FY96:
\end{abstract}

1. Completing the PPOA training module specific to Environmental Restoration activities,

2. Providing PPOA training and technical assistance to interested DOE personnel and DOE contractors, and

3. Implementing and maintaining the DOE-wide PPOA database.

This report documents the FY96 efforts, lessons learned, and future plans for all of the PPOA-related activities.

\title{
Summary
}

The Department of Energy and its contractors are faced with environmental concerns and large waste management costs. Federal legislation and DOE Orders require sites to develop waste minimization/pollution prevention programs. In response to these requirements, the Kansas City Plant developed a pollution prevention tool called a pollution prevention opportunity assessment (PPOA). Pilot assessments resulted in the development of a graded approach to reduce the amount of effort required for activities that utilized less hazardous and/or low-volume waste streams. This methodology was modified to meet the needs of other DOE sites in FY94 and validated in FY95.

The project's objectives in FY96 were to complete the PPOA training module specific to Environmental Restoration activities, to provide PPOA training and technical assistance to interested DOE personnel and DOE contractors, and to implement and maintain the DOE-wide PPOA database.

KCP continued to deliver the performance-based PPOA training class utilizing Total Quality principles and participant involvement. A new training course was developed to emphasize the application of PPOAs to environmental restoration (ER) activities. The software was also updated to reflect the changes in terminology. Brochures and articles were mailed to past pollution prevention conference attendees as well as the PPOA contacts. Six classes were delivered to 91 people--four classes were routine PPOA classes and two were ER-specific PPOA classes. The total PPOA attendance to date (FY93-FY96) is 654. 
The following progress was made in FY96 to implement the DOE-wide PPOA database: the DOE complex networking needs were defined; a DOE PPOA data request was distributed; an Internet homepage was established; 274 additional PPOA records were loaded, bringing the total number of PPOA records to 1158 from 13 different DOE sites; the database was released outside the KCP computer security wall; a URL address was assigned for internet use; hotlinks were established to and from the DOE EPIC bulletin board; and the use and availability of the DOE-wide PPOA database were demonstrated at the DOE P2 Conference XII. 


\section{Discussion}

\section{Scope and Purpose}

Pollution prevention opportunity assessments (PPOAs) can be used to identify the nature and amounts of waste and energy usage from processes and projects within a site's operations, identify the opportunities that exist for pollution prevention and energy conservation, and then evaluate those opportunities for feasible implementation.

PPOAs also provide baseline data from which progress can be measured. Therefore, PPOAs can be the foundation for a comprehensive and effective pollution prevention program. The purpose of this project was to share the methodology and experiences of the five-year-old PPOA program at the Kansas City Plant (KCP) with other DOE personnel and DOE contractors. This consisted of three major activities in FY96:

1. Completing the PPOA training module specific to Environmental Restoration activities,

2. Providing PPOA training and technical assistance to interested DOE personnel and DOE contractors, and

3. Implementing and maintaining the DOE-wide PPOA database.

\section{Activity}

\section{General Background}

The Kansas City Plant has a well-developed, site-specific PPOA methodology. Lessons learned from pilot assessments in manufacturing, nonmanufacturing, and laboratory operations led to the development of model worksheets, a PPOA Guidance, performance-based training, and graded approach methodology. This project was initiated in FY93 to share this methodology and lessons learned with others in the DOE complex. The milestones in FY93 included the following:

1. Modification of KCP's Graded Approach methodology with the assistance of DOE/DP's laboratories and

2. Delivery of PPOA training and technical assistance to interested DOE personnel and DOE contractors.

KCP tailored the scope of its site-specific PPOA training module to meet the needs of other DOE sites and contractors. A two-day, performance-based training class was designed, piloted, and delivered to $66 \mathrm{DOE}$ and DOE contractors. An annual project report was written and issued. 
In FY94 the project milestones included the following:

1. Testing DOE's PPOA graded approach methodology,

2: Providing PPOA training and technical assistance to interested DOE personnel and DOE contractors,

3. Developing and conducting a PPOA advertising campaign throughout DOE,

4. Conducting a feasibility study to develop a DOE-wide PPOA information exchange mechanism, and

5. Organizing and coordinating information sharing among related EM-352 pollution prevention projects.

The validation of DOE's PPOA graded approach methodology was initiated in FY94 with the funding of PPOAs throughout the complex. The PPOA Graded Approach methodology developed for the DOE complex in FY93 was added to the DOE Defense Programs' Pollution Prevention Opportunity Assessment Guidance. KCP also continued to deliver the performance-based PPOA training. A logo was created for both PPOAs and for pollution prevention to promote the purpose of each. These logos were utilized in class materials, presentations, and brochures. Seventeen classes and two workshops were delivered to approximately $390 \mathrm{DOE}$ personnel and DOE contractors. The Quality Function Deployment (QFD) tool was used to complete a feasibility study for the PPOA information exchange mechanism. A multisite team representing the DOE complex was used to identify customer needs and desires. A cost/benefit study was completed for each option identified in the QFD study and a recommendation made. Finally, the DOE EM Pollution Prevention Conference X, May 2-5, 1994, in Denver, Colorado, was used as a convenient location to gather the project leaders of DOE EM-334's pollution prevention projects. Information was exchanged and an agreement was made to share quarterly reports between principal investigators. An annual project report was written and issued (Reference 1).

In FY95 the project milestones included the following:

1. Validating DOE's PPOA graded approach methodology,

2. Providing PPOA training and technical assistance to interested DOE personnel and DOE contractors,

3. Enhancing the methodology with energy analysis and tools for environmental restoration (ER) activities,

4. Implementing a DOE-wide PPOA database, and

5. Providing support to the DOE EM-334 in the completion of a report which indicated the future potential for pollution prevention and waste minimization in the DOE complex. 
The DOE PPOA graded approach methodology was validated at the May 1995 DOE P2 Conference $\mathrm{XI}$ in Knoxville, Tennessee. The changes developed through this validation were added to a draft revision of the DOE Model PPOA Guidance. The PPOA training material was enhanced in FY95 with energy analysis and a section specific to ER activities. The software was also updated to reflect these changes. Of these changes, three new worksheets were added for energy analysis, and the Return-on-Investment (ROI) calculation used by DOE Headquarters was added to the economic option evaluation worksheet. In total, 12 classes were delivered to 200 people and over 160 hours of technical assistance were provided to over 20 DOE sites. A follow-up survey was conducted to measure the effectiveness of the training. The following progress was made in FY95 to implement the DOE-wide PPOA database: the software was selected and coded, the DOE's networking needs were identified through a survey, a data request was distributed to the DOE sites, and 884 PPOAs were loaded. Finally, DOE EM-334 expressed the need to provide an estimate of DOE's future waste reduction potential from the implementation of $\mathrm{P} 2$ opportunities. The KCP provided the input for the EM-30 routine waste streams and operations. The report was titled, Potential Pollution Prevention and Waste Minimization for Department of Energy Operations (Reference 2). An annual project report was written and issued (Reference 3).

\section{Environmental Restoration Training Module}

\section{Background}

The most common myth about PPOAs is that they cannot be used to evaluate nonroutine waste streams or project-oriented activities. Many DOE sites have ER missions which generate significant waste. ER missions include both remedial and decommissioning activities. The waste streams from these activities are often considered nonroutine and project-oriented. This is because decommissioning usually involves removing buildings and remediation usually requires treatment of soil and returning the land to its natural state. By modifying the point at which PPOAs are conducted or by changing one's point of view, PPOAs can be used to reduce waste from ER and other nonroutine activities.

A special concern of ER waste streams is that a large portion of the waste is already generated--"primary" waste. Since the activities involve cleaning up or tearing down existing wastes or structures, some claim that no pollution prevention can be accomplished. DOE contractors have already proven that $\mathrm{P} 2$ can be accomplished by extensive recycling of concrete and steel from decommissioning, as well as other projects which involve decontamination followed by reuse or recycling. The key is to prevent generation of "secondary" waste (waste generated in the course of performing ER activities) as much as possible (source reduction) and to also accept and embrace recycling and reuse as excellent and viable methods of $P 2$ for ER waste streams. 
Project-oriented and nonroutine waste-generating activities can be addressed by PPOAs in several ways. First, a macro-level view can be taken, looking for consistent general activities (part of a long series of routine processes) or as common waste streams. An example of a series of routine processes would be the decommissioning of many buildings over years of cleanup. This long-term perspective allows the consideration of equipment and initiatives that can be used on multiple projects, as well as development of lessons learned from one project to another. Other consistent ER activities can include the use and management of personal protective equipment (PPE). A PPOA on this waste stream could result in facility-wide PPE procedure changes that could have a large impact when implemented.

The second way to address ER projects is to implement the PPOA at the planning phase. This means reviewing the project scope and project plan in the same way an ongoing activity would be reviewed, although on paper. This can be done at a high level, such as a Record of Decision, or lower, such as specific work plans. The steps can be mapped, inputs and outputs identified, and brainstorming done on areas that will generate waste. All applicable and cost-effective ways of reducing waste can then be written into plans.

FY96 Environmental Restoration Training Module Schedule and Milestones

Develop exercises specific to ER PPOAs.

Critique of ER Training Module by other ER sites.

Advertise availability of PPOA-ER training.

Deliver PPOA training as requested.

Document FY96 efforts and lessons learned.
FY96-1Q

FY96-2Q

FY96-3Q

FY96: 3Q-4Q

FY96-4Q

The KCP teamed with representatives from Lockheed Martin Energy Systems - Oak Ridge and International Technology Corporation - Cincinnati to develop the PPOA class specific to environmental restoration. The P2/ER concepts section of the training course was taken from a report written by the representative from International Technology Corporation - Cincinnati. A draft training outline was first developed in March 1996. See Appendix A for the final PPOA-ER outline. Two exercises were created for the ER class: the first involved the dismantlement of a building and the second involved soil remediation. The dismantlement exercise was largely taken from a PPOA completed at the Fernald Site. An environmental hierarchy exercise specific to ER was also developed to help provide the culture change needed to implement $P 2$ into ER. (See Appendix B.) 
A meeting was held with International Technology Corporation - Nevada Test Site on June 25,196 , to review the draft PPOA-ER materials. Representatives from the following locations were in attendance:

IT Corporation - Nevada

AlliedSignal Inc. - Kansas City Plant

Lockheed Martin Energy Systems - Oak Ridge

IT Corporation - Nevada

AlliedSignal Inc. - Kansas City Plant

IT Corporation - Nevada

Several sections of the training material were reordered and other changes were suggested as a result of this meeting. In addition, an ER/P2 videotape was discovered. IT Corporation was just completing a videotape specific to ER activities which highlighted $\mathrm{P} 2$ examples that had been implemented across the DOE complex. An agreement was reached for its use in the PPOA-ER class.

The DOE Pollution Prevention Conference XII was attended on July 7-9, 1996, in Chicago, Illinois. A brochure was distributed at the PPOA poster session which advertised the availability and schedule for the PPOA class designed for ER.

Another evaluation of the PPOA-ER training materials occurred at a pilot class at the Oak Ridge K-25 site on July 30-31, 1996. This class did not include the software training. Ten people attended the PPOA-ER course and provided feedback for its improvement. Overall, the response was positive. Most attendees felt that they had already been implementing P2 into their ER activities but had not been documenting the information or taking any $\mathrm{P} 2$ credit.

In August 1996, the worksheet software was modified to support the PPOA-ER class. (See Appendix C.) In addition, a PPOA-ER class was held at the Kansas City Plant with 8 people in attendance. Therefore, a total of 18 people attended the PPOA-ER training in FY96.

\section{PPOA Training and Technical Assistance}

\section{Background}

In FY93, the Kansas City Plant (KCP) developed a performance-based PPOA training course for the Department of Energy and its contractors. The approach for this course was modified from the site-specific KCP program to address pollution and waste concerns that existed across the DOE complex. The assessment process was streamlined and a new series of worksheets designed. The training was divided into twelve modules with a premium placed on instructor/student interaction through the use of examples and exercises. The course included modules on pollution prevention concepts, development of a pollution prevention program, the application of Total Quality to pollution prevention, two class exercises, the DOE graded approach methodology, the computer software database for recording PPOA information, and an opportunity for participants to share lessons learned. The training materials were evaluated and refined 
over several pilot courses. Three classes were offered in FY93 with 66 participants. Feedback from the classes and support from the DOE indicated a strong demand for this type of training.

In FY94 two logos were designed to promote DOE as the leader in pollution prevention and universally applied to all DOE sites. "Partner with the Environment" was chosen to represent pollution prevention in general while "Creating Solutions, Not Pollution" was chosen to coordinate with PPOAs. These logos are proudly displayed on the front and back of the training notebook and classroom tote bag. In FY94, 297 additional DOE and DOE Contractors were trained.

In FY95, the training material was again enhanced to include energy analysis and a new section on the application to Environmental Restoration activities. Three new worksheets were developed and added to the PPOA computer software to support the energy usage/conservation opportunity documentation. A tool slide-out was developed to provide an aid for classroom attendees in the use of pollution prevention and PPOA tools. The PPOA database software was upgraded to enhance retrieval of PPOA data and worksheets and to incorporate Style III--radioactive waste categories detailed to the level of the DOE Annual Waste Generation and Waste Reduction Report. A follow-up survey was distributed to 228 past participants to determine if the training was helpful in initiating their program and if additional support was needed. In FY95, 200 additional DOE and DOE contractors attended the PPOA training class.

FY96 PPOA Training and Technical Assistance Schedule and Milestones

Receive approval and funding for project.

Update DOE PPOA Contact List.

Advertise availability of PPOA training.

Update DOE Model PPOA Guidance.

Update Train-the-Trainer PPOA manual.

Revise current training program and class room

materials to include energy analysis.

Deliver PPOA training as needed.

Provide PPOA technical assistance as

requested.

Document training and assistance through an

annual report and recommend future initiatives.
FY96-1Q

FY96-1Q

FY96-1Q

FY96-2Q

FY96-3Q

FY96-3Q

FY96:1Q-4Q

FY96:1Q-4Q

FY96-4Q 


\section{Advertising and Promotion}

A four-fold brochure was developed for DOE-HQ to advertise the PPOA class to the Pollution Prevention Field Coordinators and for distribution at the annual DOE P2 Conference. The brochure described the major tools of the PPOA project: training, technical assistance, and the use of the DOE-wide PPOA database. The FY96 PPOA training schedule was also advertised on DOE's EPIC database, the Pollution Prevention Advisor, and the Kansas City Plant's Internet homepage.

\section{Class Delivery}

In FY96, 91 DOE and DOE contractors attended PPOA classes--73 attended the routine PPOA course while 18 attended the PPOA-ER course as noted below. A list of acronyms follows the text.

\begin{tabular}{|c|c|c|c|}
\hline & $\begin{array}{l}\text { PPO } \\
\text { Class }\end{array}$ & $\begin{array}{l}\text { raining } \\
\text { endance }\end{array}$ & the \\
\hline Date & Location & \# Attended & Cumulative Total \\
\hline 1/9-11/96 & Rocky Flats & 24 & 24 \\
\hline $2 / 27-29 / 96$ & KCP & 12 & 36 \\
\hline $4 / 30-5 / 2 / 96$ & KCP & 5 & 41 \\
\hline 7/17-18/96 & LBNL & 32 & 73 \\
\hline * $7 / 30-31 / 96$ & OR K-25 & 10 & 83 \\
\hline * $8 / 20-22 / 96$ & KCP & 8 & 91 \\
\hline
\end{tabular}

Figures 1 and 2 show the distribution of attendees by DOE Operations/Field Office and by lead Cognizant Secretarial Office (CSO), respectively. 


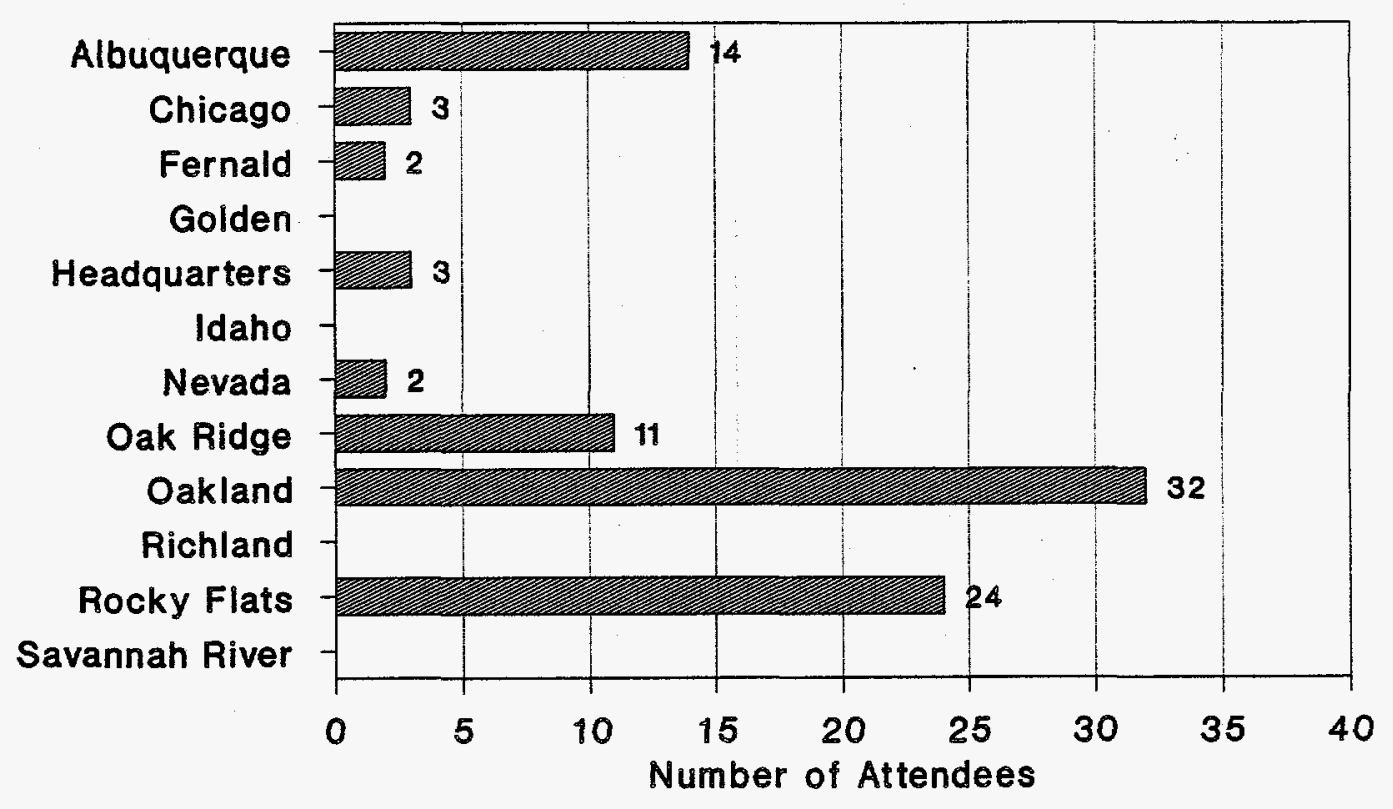

Figure 1. PPOA Training Class Attendees by DOE Operations/Field Office

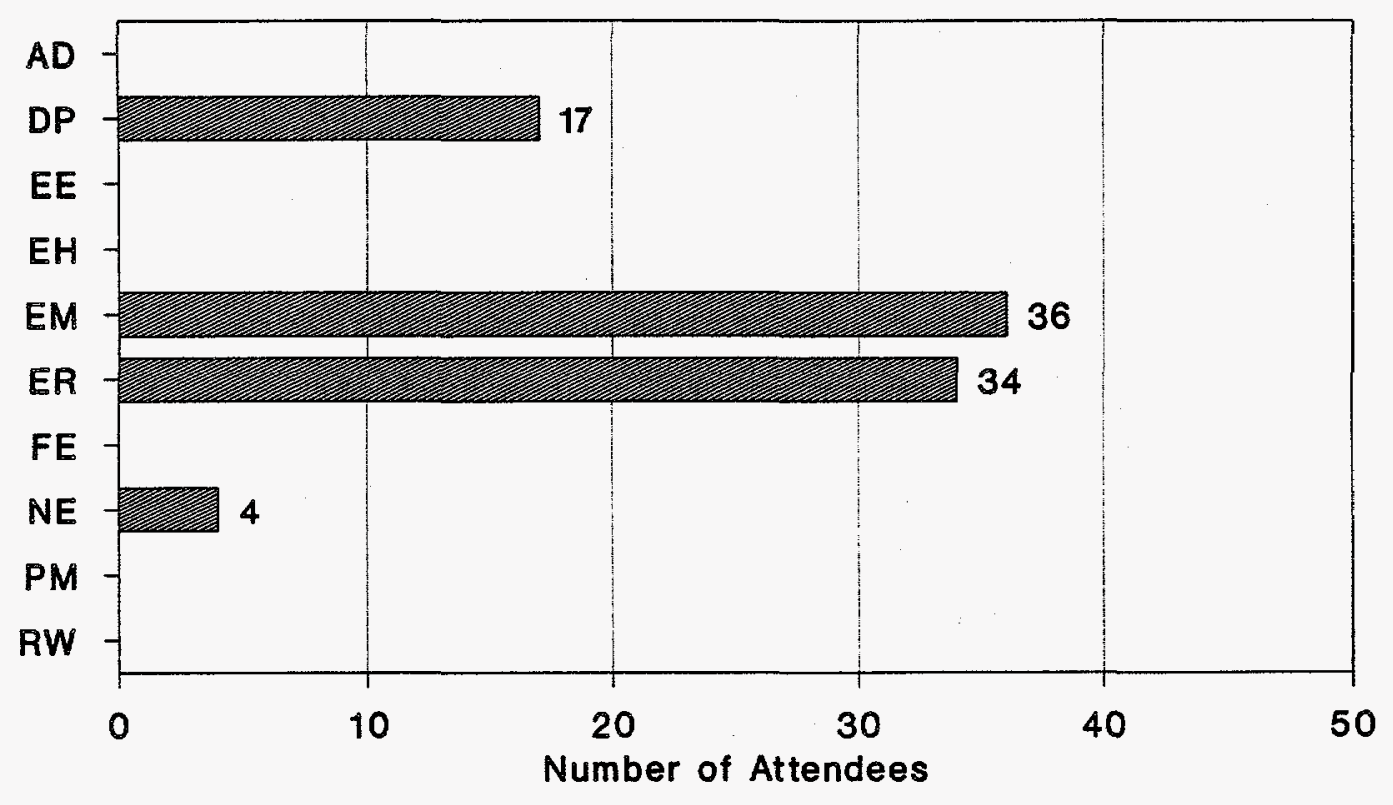

Figure 2. PPOA Training Class Attendees by Lead Cognizant Secretarial Office 


\section{Technical Assistance}

Technical assistance has also been provided on PPOAs throughout the year.

Assistance has included software support, guidance reviews, and information exchange to name a few. In addition, the Kansas City Plant coordinated the PPOA poster session at the DOE P2 Conference XII.

Technical assistance has been provided to the following sites:

Site

Oak Ridge

Indiana Department of Environmental Management

Nebraska Department of

Environmental Quality

Oak Ridge

Los Alamos National Laboratory

Pantex

Lawrence Berkeley National Laboratory

Fernald Site

Oak Ridge

Savannah River Site

Rocky Flats

Idaho National Engineering Laboratory

Savannah River Site

DOE EM-77

Wastren

SAIC

\section{Type of Assistance}

Draft Guidance Model Worksheets

P2 Examples and DOE Model PPOA Guidance

KCP Regulatory Worksheets

Priority Waste Stream List Questions and Application of Weighted Sums methodology

PPOA Training Notebook, Train-the-Trainer, and Model DOE PPOA Guidance

Updated PPOA Software

Updated Software and Recycler Contact

Updated Software

Carpenter and Fluorescent Lighting PPOAs

1994 and 1995 PPOA Project Reports

Past PPOA Attendee Lists and Updated Software

Fluorescent Bulb PPOA

Database Fields

Lesson Plan and Training Materials

PPOA Attendee Search

Updated PPOA Software and Use

Example PPOA for EPIC 
Hanford Site

DOE EH-22

IT Corporation

University of Nebraska

Sandia National Laboratory

Lawrence Berkeley National Laboratory

Oak Ridge National Laboratory

DOE EM-77

Idaho National Engineering Laboratory

University of Louisville

Idaho National Engineering Laboratory

DOE Oakland

Oak Ridge

Lawrence Livermore National Laboratory

Savannah River Site

Oak Ridge

Pantex

Western Area Power Administration

DOE DP
PPOA Graphics, Software Update, and Cutting Fluid Contact

Course Outline, Notebook, and Model PPOA Guidance

Model PPOA Guidance

Train-the-Trainer Notebook

Train-the-Trainer Notebook

Model PPOA Guidance

Model PPOA Guidance

Model PPOA Guidance

Model PPOA Guidance

PPOA Class Outline

Example Technical PPOAs

PPOA-ER Class Outline and Brochure

Priority Ranking Questions and Guidance

Software Upgrade

Database Access

P2/ER Guidance

Database Access

How to Perform Database Searches

PPOA-ER Class Notebooks

\section{Lessons Learned}

Class sizes were smaller at the Kansas City Plant due to cutbacks in travel budgets across the DOE complex. Therefore, fewer classes will be scheduled at the KCP and more will be planned off-site when the numbers are sufficient to warrant the travel. 
Implementation of an ER section in the routine manual to show how PPOAs could be applicable to ER activities was insufficient. Feedback from class participants indicated that they needed ER examples to show how ER could apply. Therefore, two PPOA classes are now available--a routine class for continuous processes and activities and a class which is project oriented and specific to ER activities. Both are two and a half days in length.

\section{Other Improvements}

The return on investment formula was updated to the current DOE headquarters usage which includes the determination of post project termination costs on Worksheet 8. (See Appendix C.)

The DOE PPOA contact list was updated to include e-mail addresses. This list is presented in the resource section of the PPOA training notebook.

The Train-the-Trainer manual and PPOA software manual were updated to include the energy analysis material. Copies of the Train-the-Trainer were distributed to those who requested it and to new PPOA training staff. The Software Manual was added to the PPOA notebook.

\section{Class Examination and Evaluation}

After the PPOA training is complete, a class examination and evaluation are filled out by the class attendees. The results of these documents are analyzed to provide a measure of how well the course objectives were met. The course evaluation also provides a forum for the class attendees to make written comments about the strong and weak points of the training. These comments have been instrumental in making improvements to the training. Figures 3 and 4 summarize the results from the course examination and evaluation for both the routine and ER-specific training, respectively. Please note that the evaluation results and examination scores are averages for each class. 


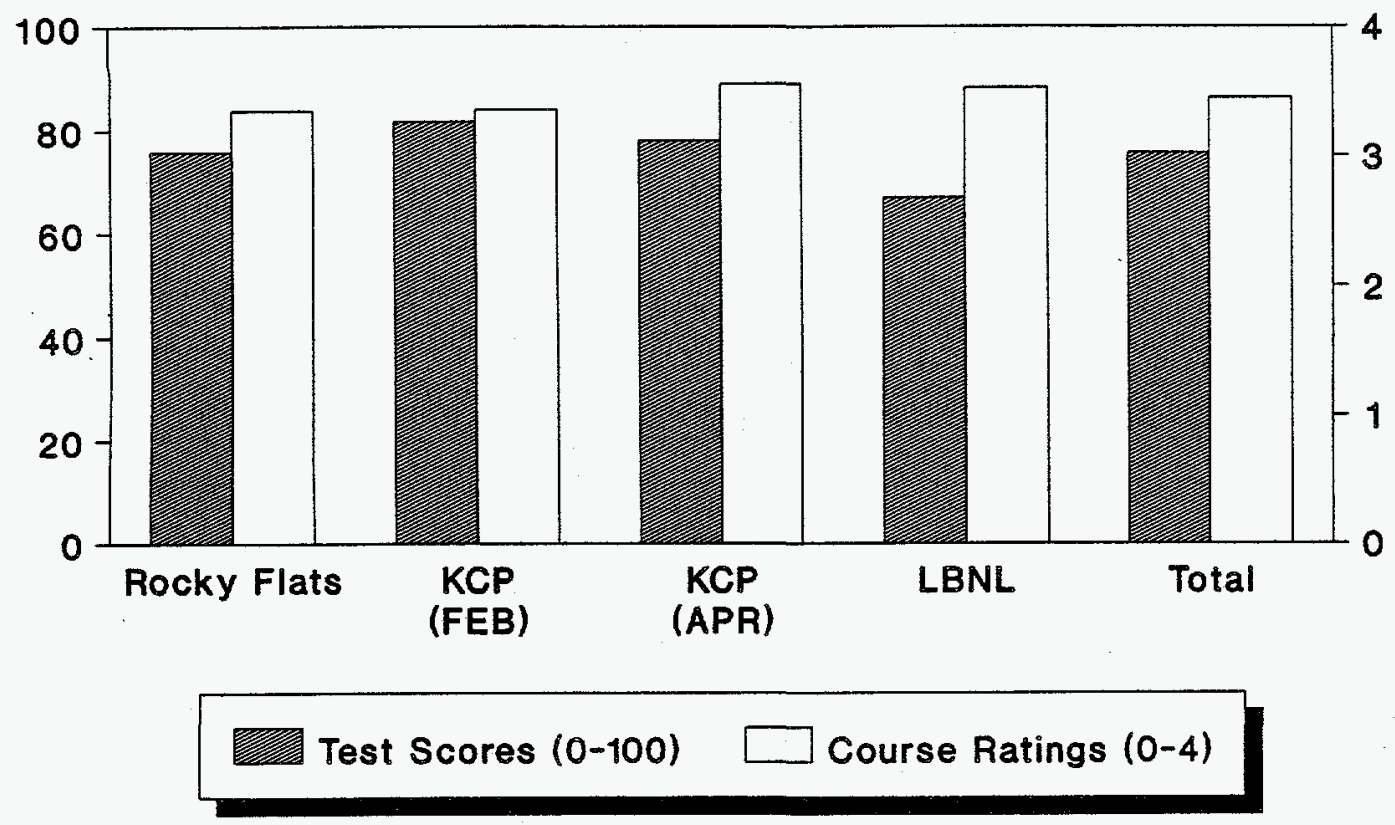

Figure 3. PPOA Training Class Results - Routine PPOA Course

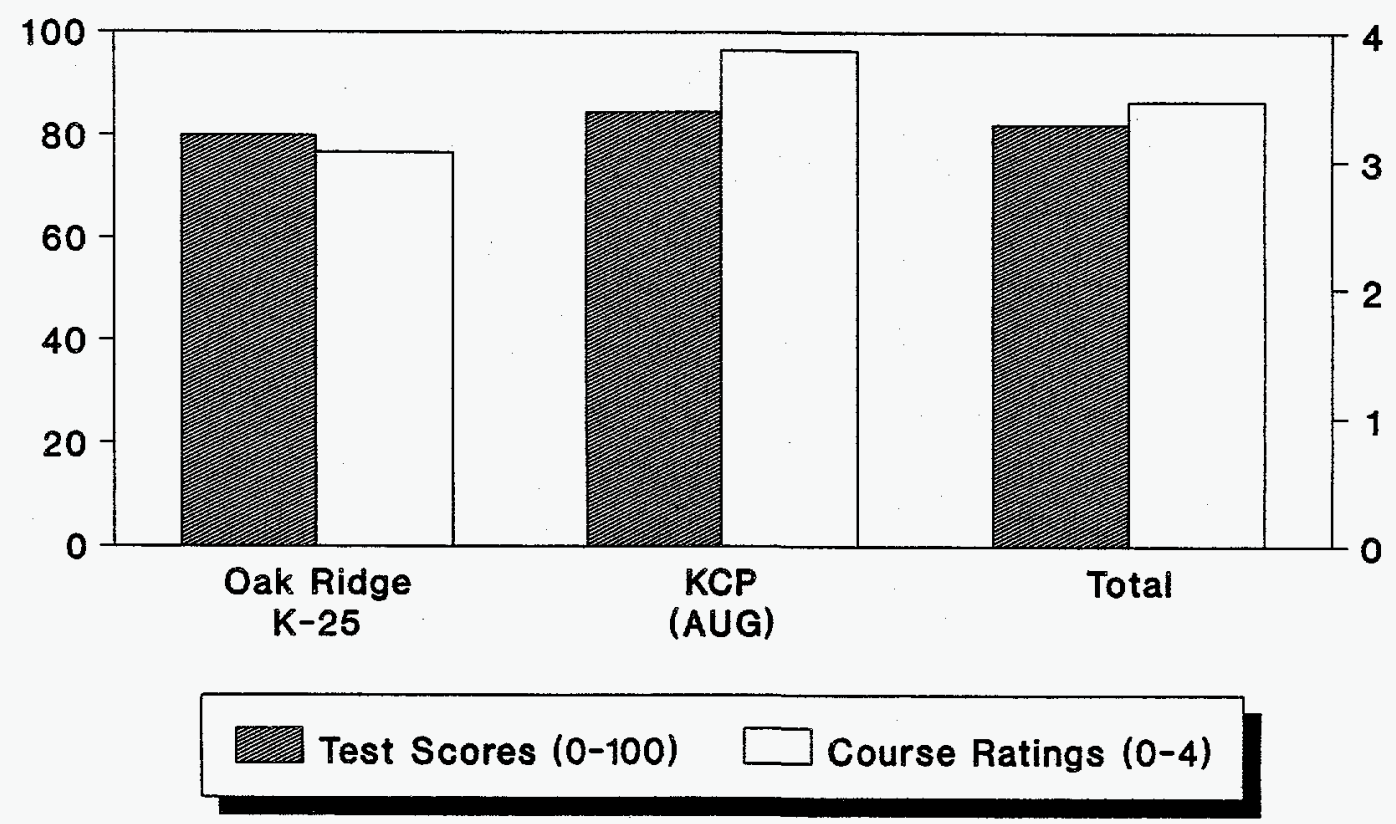

Figure 4. PPOA Training Class Results - ER-Specific PPOA Course 


\section{DOE DP Model PPOA Guidance Update}

A level III energy example and Design for Environment reference were added to the draft revision of the DOE Model PPOA Guidance. In addition, a new section was added on application to nonroutine activities. This included environmental restoration projects and new/modified facility design projects. Alternative methods were also discussed to emphasize the flexibility in using the model guidance. In November 1995 the suggested revision to the Model DOE PPOA Guidance was sent to DOE Defense Programs for review and release approval by DOE Defense Programs. Their review comments were incorporated into the document, and in February 1996 the guidance was published and distributed (Reference 4). In addition, 34 copies of the guidance were distributed to a list generated at the DOE P2 Conference XII.

\section{Benchmarking}

The Government Institute's class on "Pollution Prevention/Waste Minimization for Federal Facilities" was benchmarked on June 26-27, 1996. Several exercise techniques were noted as beneficial. However, the inclusion of DOE and radioactive waste coverage was found to be lacking.

\section{Implementation of DOE-Wide PPOA Database}

\section{Background}

Many sites within the Department of Energy have completed opportunity assessments. Others are just starting. DOE EM-77 recognized the need for these sites to share their information. Several benefits are achieved when information sharing is effective, such as (1) the elimination of redundant efforts, (2) the minimization of resources, and (3) the creation of valuable contacts. Therefore, EM-77 asked the Kansas City Plant to complete a feasibility study on a DOE-wide PPOA information exchange mechanism.

In FY94 this study was completed with a multisite team. Consensus within the team indicated that the minimum amount of PPOA information to be exchanged among DOE contractors was as follows. (This is referred to as "basic PPOA information.")

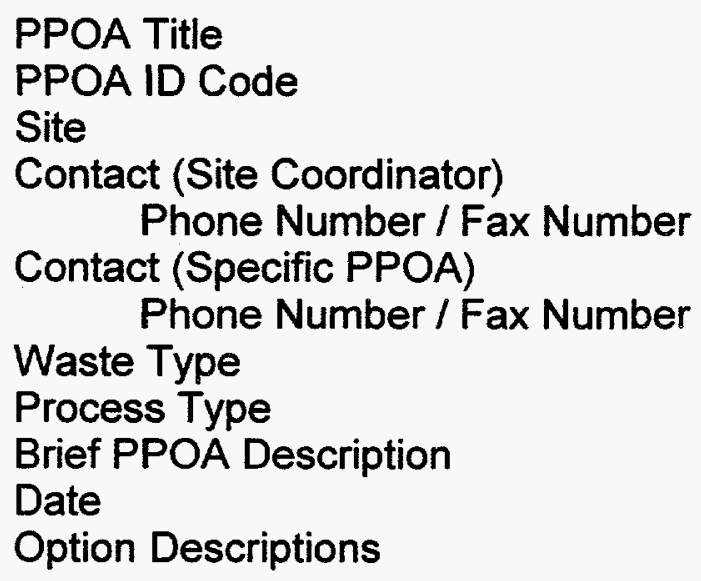


Information sharing options were generated as a result of the QFD study and a cost/benefit analysis was completed for each. Based on the following criteria of option cost information, technical evaluation, Quality Function Deployment results, and speed of completion, a recommendation was made to DOE EM-77 to implement a central database of basic PPOA information using a dedicated PC followed by implementation using the Internet.

FY96 Implementation of DOE-Wide PPOA Database Schedule and Milestones

Receive approval and funding for project

Distribute database users guide.

Request, collect, and load additional PPOAs.

Survey users for improvements and implement significant suggestions.

Maintain PPOA database and respond to user requests for data.

Document FY96 activities in an annual report and make future recommendations.
FY96-1Q

FY96-1Q

FY96-2Q

FY96-3Q

FY96:1Q-4Q

Two hundred seventy-four additional off-site PPOA records were loaded into the database in FY96, providing a total number of 1158 PPOA records. Reminder telephone calls were made to sites with PPOAs that had not sent their data. See the listing below for the number and origin of PPOA records in the DOE-wide database at the end of FY96.

DOE Site

Argonne National Laboratory - East Brookhaven National Laboratory

Fernald Environmental Management Project

Hanford Site

Idaho National Engineering Laboratory

Kansas City Plant

Nevada Test Site

Oak Ridge

PETC
PPOAs in Database

11

1

6

124

33

841

42 
Rocky Flats Environmental

Technology Site

Sandia National Laboratories

Savannah River Site

West Valley Demonstration Project

TOTAL

Technical, legal, and security approvals were authorized for external release (outside the computer security protection system at the Kansas City Plant) of the DOE-wide PPOA database. A homepage and Internet address were established for the database and Internet access was tested (locally and out of state).

The availability and use of the DOE-wide PPOA database by Internet access was demonstrated at the DOE P2 Conference XII's PPOA poster session in July 1996. Hotlinks were established to and from the DOE EPIC bulletin board for integration and sharing of P2 information. The URL address for the DOE-wide PPOA database is

http://ppoa.os.kcp.com or 199.89 .130 .30

A database verification was conducted from an internal FileMaker Pro database to the external Ingress database for Internet access. Several search comparisons showed some errors in the Ingress programming. The results were provided to the programmer so that adjustments could result in improvements to the external system.

The following searches were performed with the database.

Site

DOE EM-77

Oak Ridge

Rocky Flats

IT Corporation

Idaho National Engineering Laboratory

\section{Database Search Provided}

Contaminated Soil PPOAs

Low Level Waste PPOAs

Painting, Leaded Glass, Batteries, Solvent Substitution, and Photolithography PPOAs

ER PPOAs

Plutonium and Nuclear Waste Production PPOAs 


\section{Accomplishments}

The following accomplishments have been realized as a result of this project in FY96:

- Ninety-one DOE and DOE contractors received PPOA training--18 attended the ERspecific class and 73 attended the routine class.

- The PPOA training materials were revised based on lessons learned from FY95.

- A new set of PPOA training materials was developed for application to ER activities. The worksheets and worksheet software were updated to include the new terminology needed for the ER course.

- The DOE Model PPOA Guidance was updated to include energy analysis and application to nonroutine activities.

- The Return-on-Investment (ROI) calculation was updated to reflect what is being used by DOE Headquarters.

- The list of DOE PPOA contacts was updated to include e-mail addresses.

- The Software and Train-the-Trainer manuals were updated to include energy analysis.

- More than $\mathbf{4 0}$ hours of technical assistance were provided to over 22 DOE sites during FY96.

- The PPOA course was advertised through the Pollution Prevention Advisor, the DOE EPIC bulletin board, the KCP Internet homepage, and internally developed brochures. The brochures were distributed at the DOE EM P2 Conference XII in Chicago, Illinois.

- The DOE-wide PPOA database access from the Internet was completed with a total of 1158 PPOA records stored from 13 DOE sites. In addition, the database was released outside the KCP computer security wall, a link was established with the DOE EPIC bulletin board, and the use and availability of the DOE-wide PPOA database were demonstrated at the DOE P2 Conference XII. 


\section{Future Work}

The last deliverable for each project activity included the development of FY96 follow-on plans. They are as follows:

- Develop a Model PPOA Guidance specific to Environmental Restoration activities.

- Continue to provide routine and ER-specific PPOA training and technical assistance to interested DOE and DOE contractor personnel.

- Develop additional P2/ER training materials for ER project managers and field staff to ensure the culture change necessary to implement $P 2$ into the ER project level.

- Develop a PPOA training overview videotape to distribute to smaller sites within the DOE complex.

- Maintain the DOE-wide PPOA database and update the information periodically. Develop and distribute a users survey to determine user friendliness and areas for improvement. Establish and record the number of hits that the database receives. 


\section{References}

${ }^{1}$ Susan E. Pemberton, Pollution Prevention Opportunity Assessment Approach, Training, and Technical Assistance for DOE Contractors - FY94 Report. Federal Manufacturing \& Technologies: KCP-613-5545, January 1995. (Available from NTIS).

${ }^{2}$ Griffin, Ischay, Kennicott, Pemberton, and Tull, Potential Pollution Prevention and Waste Minimization for Department of Energy Operations, Lockheed Idaho Technologies Company, INEL-95/0293, October 1995.

${ }^{3}$ Susan E. Pemberton, Pollution Prevention Opportunity Assessment Approach, Training, and Technical Assistance for DOE Contractors - FY95 Report. Federal Manufacturing \& Technologies: KCP-613-5735, February 1996. (Available from NTIS).

${ }^{4}$ U.S. Department of Energy Model PPOA Guidance, prepared under the direction of U.S. Department of Energy, Office of Defense Programs, February 1996, DOE/DP-0136. 


\section{Acronyms}

AD - Department of Energy's Administration Program

ANL - Argonne National Laboratory

ADS - Activity Data Sheet

ASI/KO - AlliedSignal Inc./Kirtland Operations

BDM - BDM Oklahoma Inc.

CSO - Cognizant Secretarial Office

CSU - Colorado State University

DOE DP - Department of Energy's Defense Programs

DOE EE - Department of Energy's Energy Efficiency and Renewable Energy Program

DOE EM - Department of Energy's Environmental Management Program

DOE ER - Department of Energy's Energy Research Program

DOE FE - Department of Energy's Fossil Energy Program

DOE HQ - Department of Energy's Headquarters

EADC/IAC - Energy Analysis and Diagnostics Center/Industrial Assessment Center

ECO - Energy Conservation Opportunity

EML/NY - Environmental Measurements Lab / New York

EPIC - Department of Energy's Pollution Prevention Information Clearinghouse

ER - Environmental Restoration

FY93 - Fiscal Year 1993

FY94 - Fiscal Year 1994

FY95 - Fiscal Year 1995

FY96 - Fiscal Year 1996

KCP - Kansas City Plant

LANL - Los Alamos National Lab

LBNL - Lawrence Berkeley National Laboratory

LLNL - Lawrence Livermore National Laboratory

NE - Department of Energy's Nuclear Energy Program

NP - Department of Energy's New Production Reactor Program

NTS - Nevada Test Site

P2 - Pollution Prevention

PPOA - Pollution Prevention Opportunity Assessment

PWA - Process Waste Assessment

QFD - Quality Function Deployment

RW - Department of Energy's Civilian Radioactive Waste Management Program

SNL/CA - Sandia National Laboratories/California

SNL/NM - Sandia National Laboratories/New Mexico

TRADE - Training Resources and Data Exchange

WRITAR - Waste Reduction Institute for Training and Applications Research

WINCO - Westinghouse Idaho Nuclear Company

WSRC - Westinghouse Savannah River Company 
Appendix A

\section{PPOA-ER Course Outline}


Day \#1

Approximate Time

Registration

7:30 am

Coffee, Juice and Rolls will be provided.

1. Welcoming Remarks

8:00 am
a) Administrivia
b) Training Team Introductions \& Training Purpose

II. Introduction to the Total Quality Approach
a) Description of the Total Quality (TQ) Problem Solving Model
b) The Total Quality Approach and Continuous Improvement
c) Critical Success Factors

III. Pollution Prevention Program and Structure
a) Major Elements of a Successful P2 Program
b) Organization of a P2 Network
c) Strategies of Goal Setting
d) Theory and Steps to Determining P2 Priorities
e) P2 Drivers and How They Relate to PPOAs

IV. Pollution Prevention Concepts for Environmental Restoration
a) Definition of Pollution Prevention (P2) and Environmental Restoration (ER)
b) Application of P2 to ER
c) Environmental Hierarchy Definition \& Examples
d) ER/P2 Hierarchy Exercise
e) P2 Benefits, DOE HQ Initiatives, \& P2/ER Examples
f) P2 Tools

V. Pollution Prevention Opportunity Assessment, (Assessment Portion)
a) Pollution Prevention Opportunity Assessment (PPOA) Elements
b) Nonroutine PPOA Application and ER Case Study
c) PPOA Benefits
d) Elements of PPOA Team Formation
e) Description of the Steps to Complete an Activity Description
f) Requirements of PPOA Flow Diagrams, Material Balances, Energy Usage and Costs

Lunch (On Your Own)

$11: 30 \mathrm{am}$

V. Pollution Prevention Opportunity Assessment

(Option Generation Portion)

12:30 pm

a) Identification of Option Generation Methods

b) Description of Option Screening Techniques

c) Economic Evaluation of Options

d) Description of the Weighted Sums Prioritization Technique

e) Final Report Elements, Purpose, and Checklist

Adjourn Day 1

4:30 pm 
Day \#2

Welcome Back - Preview Day and Review Objectives

$7: 30$ am

Coffee, Juice and Rolls will be provided.

VI. Performance-Based Team Exercise, Part 1

$8: 00 \mathrm{am}$
a) Introduction of Team Exercise
b) Teams Perform Assessment Portion of PPOA
c) Review Assessment Results

VI. Performance-Based Team Exercise, Part 2

10:00 am

a) Teams Complete Option Generation and Evaluation Portion of PPOA

b) Review Option Generation and Evaluation Results

Lunch (On Your Own)

noon

VII. Graded Approach for PPOAs

a) Benefits of a Graded Approach Methodology

b) Minimum Requirements and PPOA Levels

VIII. Course Examination and Evaluation

IX. Lessons Learned/nformation Sharing (P2 and PPOA)

a) Participants are Encouraged to Share Information about their Sites

b) List of ER PPOAs Available in DOE Database

c) Technical Assistance

X. Review Course/Participants Expectations

Adjourn Day 2

4:00 pm

Day \#3

XI. Brief Overview of Breakout Sessions

\begin{tabular}{||l|l|l|l|}
\hline Computer Room & & \multicolumn{1}{|c|}{ Group 2 } & \\
\hline Conam-10:00am & $?$ & $8: 00 \mathrm{am}-10: 00 \mathrm{am}$ \\
\hline$?$ & $10: 00 \mathrm{am}-$ Noon & Computer Room & $10: 00 \mathrm{am}-$ Noon \\
\hline & & & \\
\hline
\end{tabular}


Appendix B

ER-P2 Hierarchy Exercise 

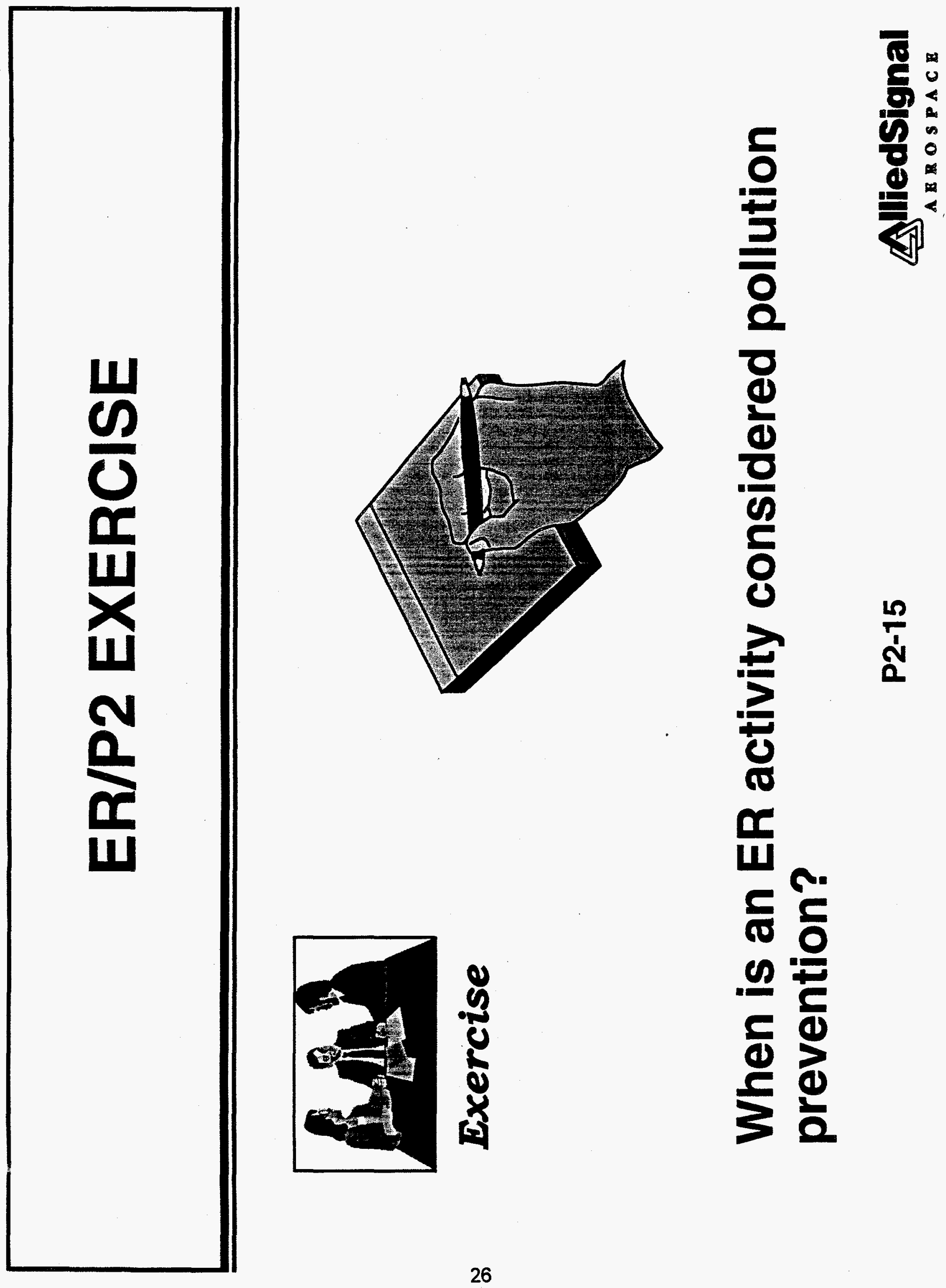


\section{Environmental Management Hierarchy Examples}

Which Environmental Management Hierarchy option best describes each of the following?

Choices: Source Reduction (SR)

Recycling / Reuse (RR)

Treatment / Controls (TC)

Disposal (DI)

1. A hazardous cleaner used for decontamination of radioactive surfaces is substituted with a nonhazardous one.

2. Free-release requirements are changed leading to a $25 \%$ reduction in primary waste removal.

3. An activated carbon filter is installed in a wastewater treatment system.

4. Liquid low-level radioactive waste is mixed with concrete prior to disposal.

5. Low-level contaminated concrete is pulverized resulting in releaseable material for use in a bedding for a new road.

6. Low-level waste is placed in containers and disposed at the Nevada Test Site.

7. Waste management changes a treatment process which results in a $50 \%$ reduction in the secondary hazardous waste stream.

8. A POTW permit on end-of-pipe $\mathrm{pH}$ levels is adjusted causing less sulfuric acid to be used.

9. The temperature and pressure of a high-pressure hot water cleaner were raised to reduce chemical usage.

10. Purchase specifications are rewritten to require the vendor to take back all packaging materials for their reuse.

11. A new procedure is implemented requiring all unnecessary packaging to be removed prior to entry into a rad-contaminated zone. 


\section{Environmental Management Hierarchy Examples}

Which Environmental Management Hierarchy option best describes each of the following?

$\begin{array}{ll}\text { Choices: } & \text { Source Reduction (SR) } \\ & \text { Recycling / Reuse (RR) } \\ & \text { Treatment / Controls (TC) } \\ & \text { Disposal (DI) }\end{array}$

12. A new decontamination technique is implemented which increases the amount of primary waste which can be reused and/or recycled.

13. Spent solvent from a decontamination process was distilled and reused.

14. The specification for fleet antifreeze is changed to extend the usage-life (based on mileage not time) before replacement.

15. A decommissioning team segregates the metal being removed for purposes of reuse or recycling.

16. A new piece of equipment is bought to treat decon wastewaters that are currently being stored and shipped for disposal. This will significantly decrease secondary waste generation and energy required for transportation.

17. An insitu treatment for soil is selected which avoids removal, shipment, and storage of the primary waste.

18. Negotiations with regulators on clean-up standards reduces the volume of waste requiring remediation.

19. A review of historical records provides adequate process knowledge to decrease the number of samples and analyses required for site characterization.

20. Primary waste is compacted and dewatered to decrease storage containers, optimize storage space, and optimize transportation energy/fuel. 


\section{ORDER OF MOST-EFFECTIVE ENVIRONMENTAL MANAGEMENT FOR ER}

ก

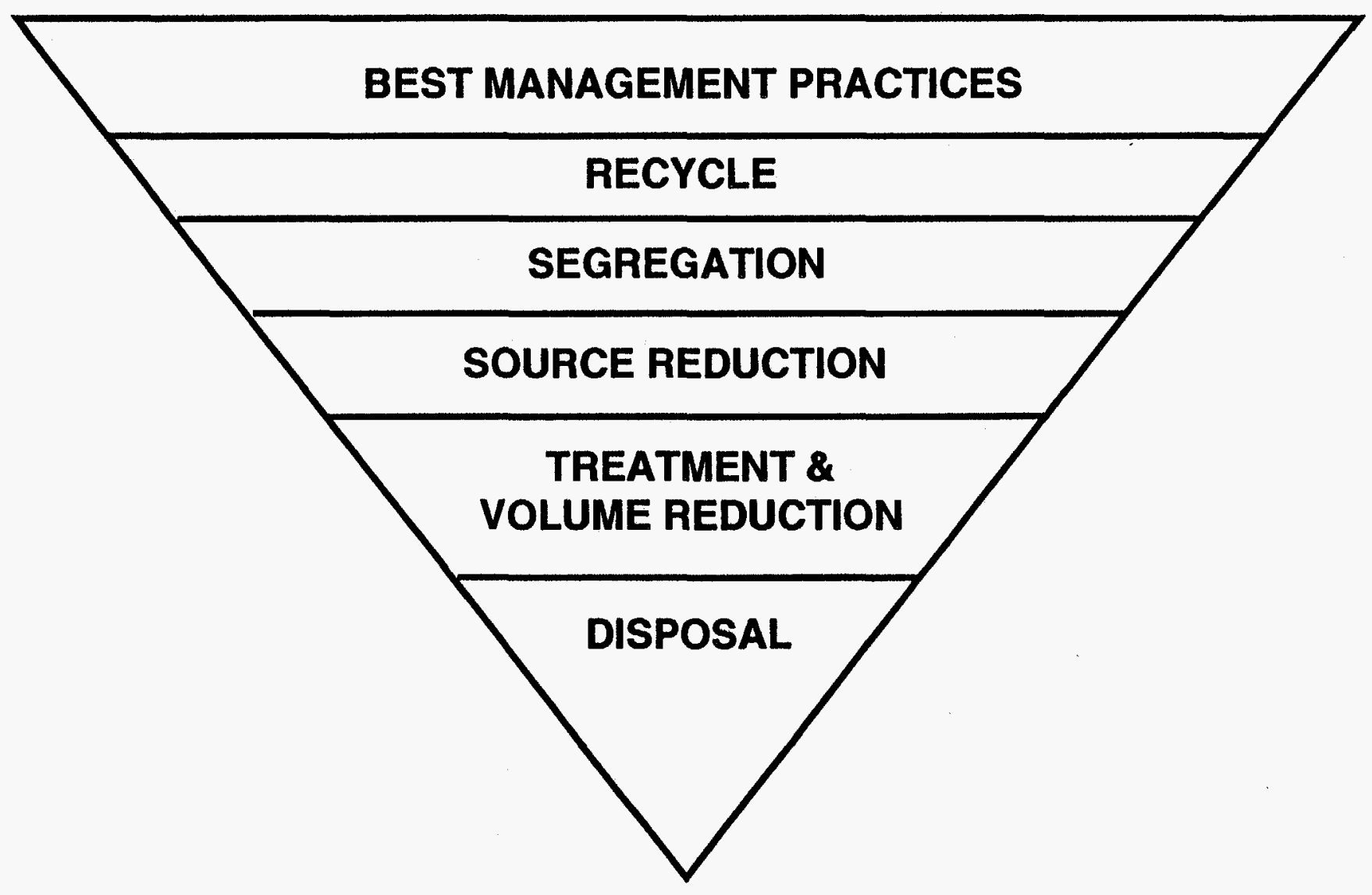

P2-16 


\section{Appendix C \\ PPOA-ER Model Worksheets}




\section{Worksheet 1 i \\ Level III \\ PPOA ID Code: \\ Pollution Prevention Opportunity Assessment \\ PPOA Team \\ PPOA Title:}

Issue Date:

Revision No.:

Revision Date:

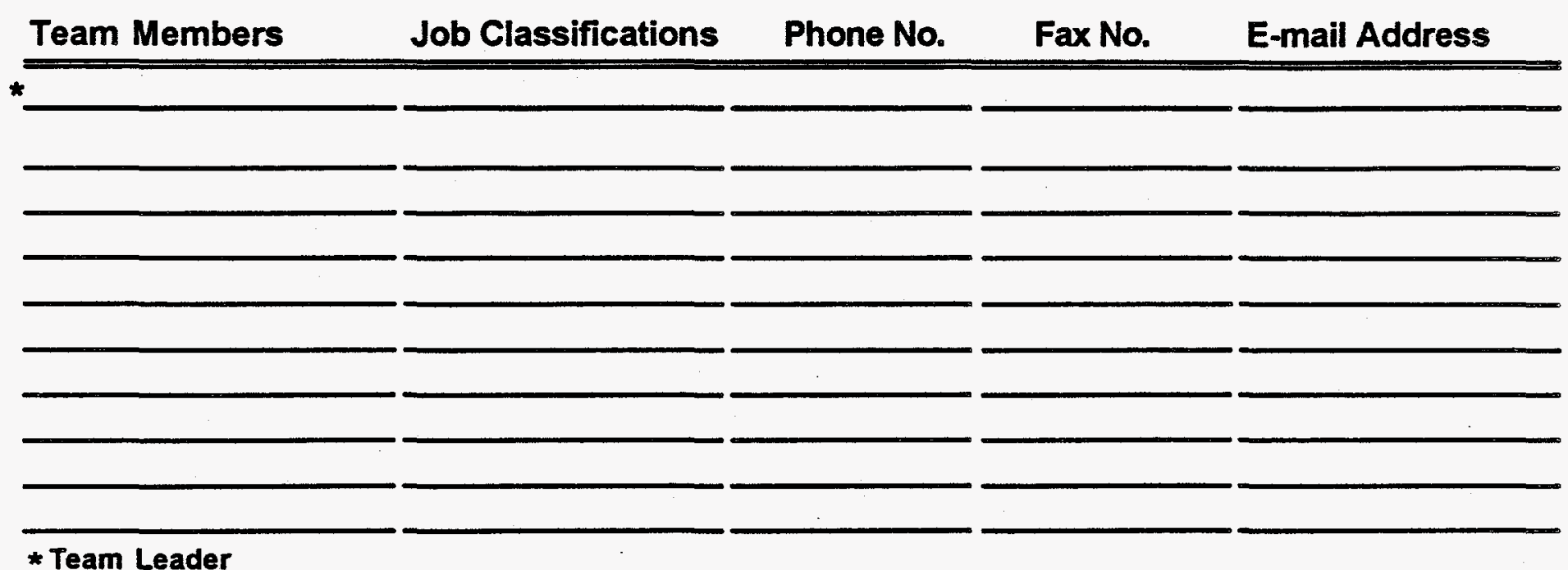

\section{Additional Resources}

Contact Name

Phone No.

Fax No.

E-mail Address

\section{Site PPOA Coordinator}

Waste Management

Industrial Hygiene

Environmental Compliance

Safety

Fire Protection

Health Physics

Cost Estimator

Engineering

Maintenance (Utilities)

Maintenance (Equipment)

Analytical Services

Scheduling

Site P2 Manager

Other 


\section{Pollution Prevention Opportunity Assessment \\ PPOA Team \\ Help}

This worksheet provides the scope and identification of the pollution prevention opportunity assessment (PPOA) team. For the PPOA to be successful, employees involved with the activity being assessed should be members of the team. The assessment team needs a leader, members, and additional resources, as required.

The team leader should have technical knowledge of the area's operations and the personnel involved. The leader shall assemble the team to perform the assessment. Team members may include pollution prevention coordinators, environmental waste engineers, design engineers, project engineers, project managers, health physics, environmental compliance, waste management specialists, and other field or project staff. Additional resources may be called in to provide information not available within the team. The size of the team may be large for complicated activities, but should be kept to a minimum to maintain focus.

To move from field to field, either use mouse and click on desired field, or use TAB key.

1. Original Issue Date: Automatically entered upon selecting NEW RECORD.

2. Revision No.: List the revision number for this worksheet. \{Original issue $=0$.

3. Revision Date: Automatically updated any time a change is made to a record.

4. PPOA Title: List the PPOA title selected by the team.

5. PPOA ID Code(s): List the PPOA ID Code(s) selected by the team.

6. Name, Job Classification, Phone No., Fax No., and E-Mail Address: To facilitate team meetings and for future reference, this information should be completed when the PPOA team is formed. 


\section{Pollution Prevention \\ Opportunity Assessment}

Level III

Revision No.:

Activity Description

PPOA ID Code:

PPOA Title:

Activity Location:

Site:

Area:

Building:

Depart:

Floor:

Room:

Activity Description:

Description of Major Product(s) of Activity or Purpose:

Major Activity Type:

Specific Activity Type:

Major Waste Type:

Specific Waste Type: 
Worksheet?

Level III

\section{Pollution Prevention \\ Opportunity Assessment}

Activity Description

Help

Worksheet 2 provides a brief description of the activity. An activity is any existing or planned project or process which uses energy and/or generates waste or pollution to the air, water, and/or land. The main elements of the activity description are the location, input materials, energy usage, equipment, summary of operations performed, controls, operator training, major products, and the waste streams affected.

1. Revision No.: List the revision number for this worksheet.

2. Revision Date: List the most recent revision date for this worksheet.

3. PPOA Title: List the PPOA title given on Worksheet 1.

4. PPOA ID Code(s): List the PPOA ID Code(s) given on Worksheet 1.

5. Activity Location: List the best descriptor of the activity location. It may be a department, building, room, etc.

6. Activity Description: The description should detail important attributes of the activity. Project's purpose, waste streams involved (primary and secondary), cleanup technology, project monitoring, secondary materials, training (qualification or certification), and energy sources may be included.

7. Description of Major Product(s) of Activity or Purpose: Describe the major products which result from this activity or the reason it is being performed.

8. Major Activity Type, Specific Activity Type, Major Waste Type, and Specific Waste Type: These fields will provide useful searching capability in the DOE-Wide PPOA database. Choose the best descriptor for these fields. A list of the available activity and waste stream lists are shown as pop-up lists. 
Level III

Revision No.: Opportunity Assessment

Revision Date:

Flow Diagram

Page:

PPOA TItle:

PPOA ID Code:

Inputs:

Material Name I

Control No.

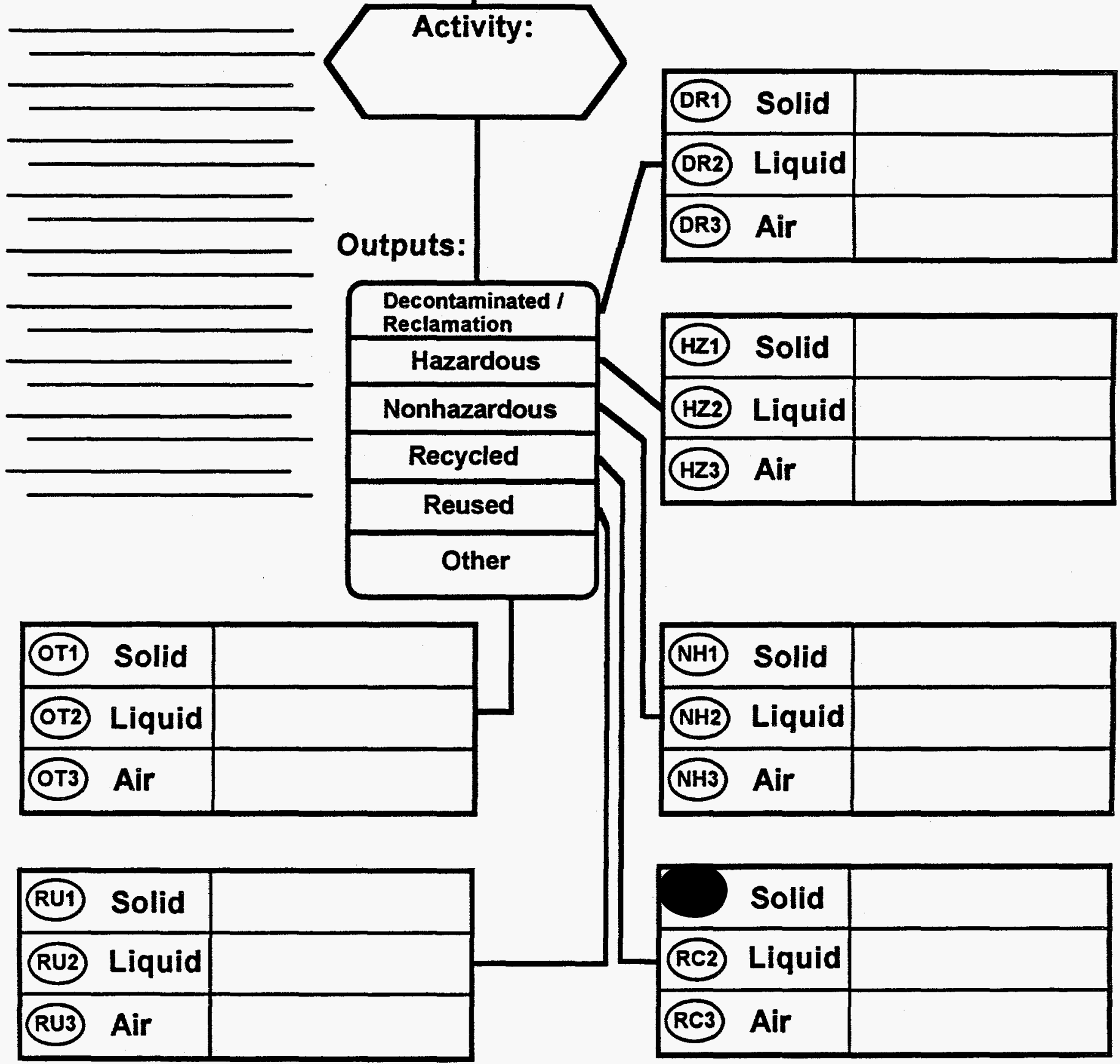


Level III

\section{Pollution Prevention \\ Opportunity Assessment}

Flow Diagram

Help

Worksheet 3 provides a flow diagram for the PPOA. The flow diagram should represent all PPOA ID Code(s) associated with the activity, all input materials, and outputs (products/wastes). The flow diagram should track materials from the time they enter the boundary of the activity until they leave. This diagram represents a very simplistic flow model; a more detailed diagram may be required to identify all waste streams, especially for complex, multi-step processes.

To move from field to field, either use mouse and click on desired field, or use TAB key.

1. Revision No.: List the revision number for this worksheet. \{Original issue $=0$.

2. Revision Date: Automatically updated any time a change is made to a record.

3. PPOA Title: List the PPOA title given on Worksheet 1.

4. PPOA ID Code(s): List the PPOA ID Code(s) given on Worksheet 1.

5. Flow Diagram: List the input materials on the lines provided. Fill in the Activity Name box. Then highlight those outputs that are applicable to the activity (e.g. Recycled, Hazardous, etc). Then categorize those outputs into solid, liquid, or air emission streams by highlighting the corresponding output stream. A Stream ID Code is provided for each category of waste.

6. Outputs: The Stream ID Code provides a uniform coding scheme for the release information requested on Worksheet 4. A brief waste description may be recorded in the box to the right of the Stream ID Code.

\begin{tabular}{lc}
\multicolumn{2}{c}{ Stream IDCodes } \\
Designator & Code \\
& \\
Decontaminated / Reclamation & $\mathrm{DR}$ \\
Hazardous & $\mathrm{HZ}$ \\
Nonhazardous & $\mathrm{NH}$ \\
Recycled & $\mathrm{RC}$ \\
Reused & $\mathrm{RU}$ \\
Other & OT
\end{tabular}

Solid Stream $=1$, Liquid Stream $=2$, Air Stream $=3$ 


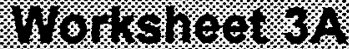

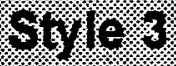

Level III

PPOA ID Code:

Material Name /

Control No.

Inputs:

\section{Pollution Prevention Opportunity Assessment}

Flow Diagram

PPOA Title:
Revision No.:

Revision Date:

Page: 1 A

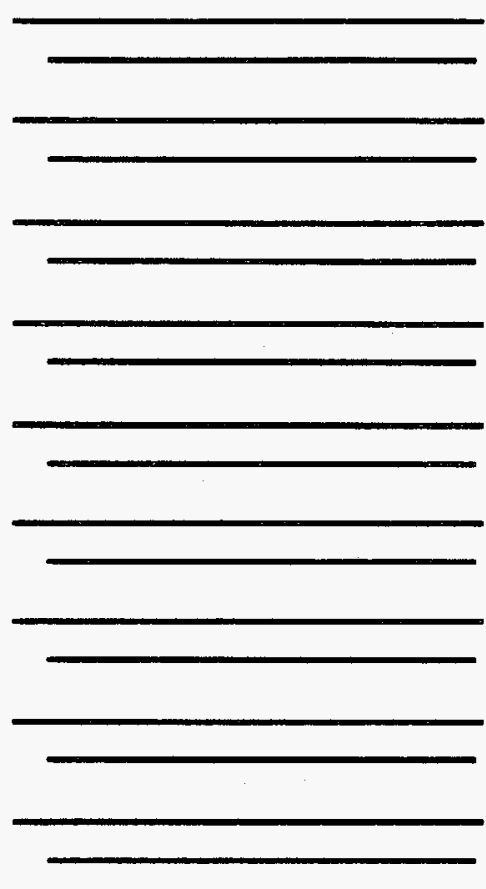

\begin{tabular}{|l|l|}
\hline TS1 & Solid \\
\hline TS2 & Liquid \\
\hline TS3 & Air \\
\hline
\end{tabular}

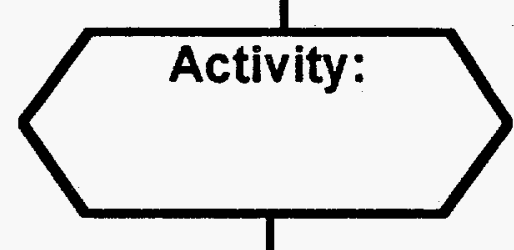

Outputs:

Decontamination/ Reclamation

\begin{tabular}{|l|l|}
\hline DR1 & Solid \\
\hline DR2 & Liquid \\
\hline DR3 & Air \\
\hline
\end{tabular}

Non-Hazardous

Hazardous - non RCRA

Hazardous - RCRA

Toxic, TSCA

Other

\begin{tabular}{|l|l|}
\hline $\mathrm{NH1}$ & Solid \\
\hline $\mathrm{NH} 2$ & Liquid \\
\hline $\mathrm{NH3}$ & Air \\
\hline
\end{tabular}

\begin{tabular}{|l|l|}
\hline OT1 & Solid \\
\hline OT2 & Liquid \\
\hline OT3 & Air \\
\hline
\end{tabular}

\begin{tabular}{|l|l|}
\hline HR1 & Solid \\
\hline HR2 & Liquid \\
\hline HR3 & Air \\
\hline
\end{tabular}




\section{Pollution Prevention Opportunity Assessment}

Level III

\section{Flow Diagram}

Worksheet 3 provides a flow diagram for the PPOA. The flow diagram should represent all PPOA ID Code(s) associated with the activity, all input materials, and outputs (products/wastes). The flow diagram should track materials from the time they enter the boundary of the activity until they leave. This diagram represents a very simplistic flow model; a more detailed diagram may be required to identify all waste streams, especially for complex, multi-step activities.

1. Revision No.: List the revision number for this worksheet.

2. Revision Date: List the most recent revision date for this worksheet.

3. PPOA Title or PPOA ID Code(s): List the PPOA Title or PPOA ID Code(s) given on Worksheet 1.

4. Flow Diagram: List the input materials on the lines provided. Fill in the Activity Name box. Then highlight those outputs that are applicable to the activity (e.g. Product, Hazardous, etc.). Then categorize those outputs into solid, liquid, or air emission streams by highlighting the corresponding output stream. A Stream ID Code is provided for each category of waste.

5. Outputs: The Stream ID Code provides a uniform coding scheme for the release information requested on Worksheet 4 . A brief waste description may be recorded in the box to the right of the Stream ID Code.

\section{DQE Definitions}

Hazardous Waste - Waste, which because of its quantity, concentration, or physical, chemical or infectious nature may (a) cause or significantly contribute to an increase in mortality or an increase in serious irreversible, or incapacitating reversible illness, or (b) pose a substantial present or potential hazard to human health or the environment when improperly treated, stored, transported, disposed of, or otherwise managed. Hazardous waste can be further defined as:

RCRA-regulated - solid waste not specifically excluded from regulation under 40 CFR 261.4, or delisted by petition, that is either a listed hazardous waste (40 CFR 261.30-261.33) or exhibits the characteristics of a hazardous waste (40 CFR $261.20-261.24$ ).

Non RCRA-regulated - any other hazardous waste not specifically regulated under TSCA or RCRA, which may be regulated by the state or local authorities, such as used oil.

TSCA Waste - Individual chemical wastes (both liquid and solid), such as polychlorinated biphenyls. 
Workstreet 313 Sille.

Level III

PPOA ID Code:

\section{Pollution Prevention Opportunity Assessment}

Flow Diagram
Revision No.:

Revision Date:

Page: 1 B

PPOA Title:

\begin{tabular}{|l|l|}
\hline OR1 & Solid \\
\hline OR2 & Liquid \\
\hline OR3 & Air \\
\hline
\end{tabular}

\begin{tabular}{|l|l|}
\hline LL1 & Solid \\
\hline LL2 & Liquid \\
\hline LLL3 & Air \\
\hline
\end{tabular}

\begin{tabular}{|l|l|l|}
\hline RC1 & Solid \\
\hline RC2 & Liquid \\
\hline RC3 & Air & \\
\hline Row & \\
\hline RC & \\
\hline
\end{tabular}

\begin{tabular}{|l|l|}
\hline RU1 & Solid \\
\hline RU2 & Liquid \\
\hline RU3 & Air \\
\hline
\end{tabular}

Outputs: Other, RAD Low Level Low Level, Mixed TRU, Mixed

ransuranic, (TRU)

High Level

Recycling Reuse

\begin{tabular}{|l|l|}
\hline LLM1 & Solid \\
\hline LLM2 & Liquid \\
\hline LLM3 & Air \\
\hline TT1 & Solid \\
\hline TM2 & Liquid \\
\hline TM3 & Air \\
\hline
\end{tabular}

\begin{tabular}{|l|l|}
\hline TU1 & Solid \\
\hline TU2 & Liquid \\
\hline TU3 & Air \\
\hline
\end{tabular}

\begin{tabular}{|l|l|}
\hline$H L 1$ & Solid \\
\hline HL2 & Liquid \\
\hline HL3 & Air \\
\hline
\end{tabular}




\section{Pollution Prevention \\ Opportunity Assessment}

Level III

Flow Diagram

Help

Worksheet 3 provides a flow diagram for the PPOA. The flow diagram should represent all PPOA ID Code(s) associated with the activity, all input materials, and outputs (products/wastes). The flow diagram should track materials from the time they enter the boundary of the activity until they leave. This diagram represents a very simplistic flow model; a more detailed diagram may be required to identify all waste streams, especially for complex, multi-step activities.

1. Revision No.: List the revision number for this worksheet.

2. Revision Date: List the most recent revision date for this worksheet.

3. PPOA Title or PPOA ID Code(s): List the PPOA Title or PPOA ID Code(s) given on Worksheet 1.

4. Flow Diagram: List the input materials on the lines provided. Fill in the Activity Name box. Then highlight those outputs that are applicable to the activity (e.g. Product, Hazardous, etc.). Then categorize those outputs into solid, liquid, or air emission streams by highlighting the corresponding output stream. A Stream ID Code is provided for each category of waste.

5. Outputs: The Stream ID Code provides a uniform coding scheme for the release information requested on Worksheet 4. A brief waste description may be recorded in the box to the right of the Stream ID Code.

\section{DOE Definitions:}

High Level Waste: - Irradiated reactor fuel, liquid wastes resulting from operation of the first cycle solvent extraction system, or equivalent, and the concentrated wastes from subsequent extraction cycles, or equivalent, in a facility for reprocessing irradiated reactor fuel, and solids into which such liquid wastes have been converted. (10 CFR 60.2)

Transuranic Waste: - Waste that is contaminated with alpha-emitting radionuclides with (1) an atomic number greater than 92 (heavier than uranium); (2) half-lives greater than 20 years; and (3) concentrations greater than 100 nanocuries per gram of waste.

Transuranic Mixed Waste: - Waste which contains both transuranic waste and hazardous components, as defined by the Atomic Energy Act and RCRA, respectively.

Low Level Waste: - Radioactive Waste not classified as high level waste, transuranic waste, spent nuclear fuel, or by-product material [specified as uranium or thorium tailings and waste in accordance with DOE Order 5820.2A]. 
Worksheet 4

Level III

Pollution Prevention Opportunity Assessment

Material Balance Summary

Time Frame

From:

To:

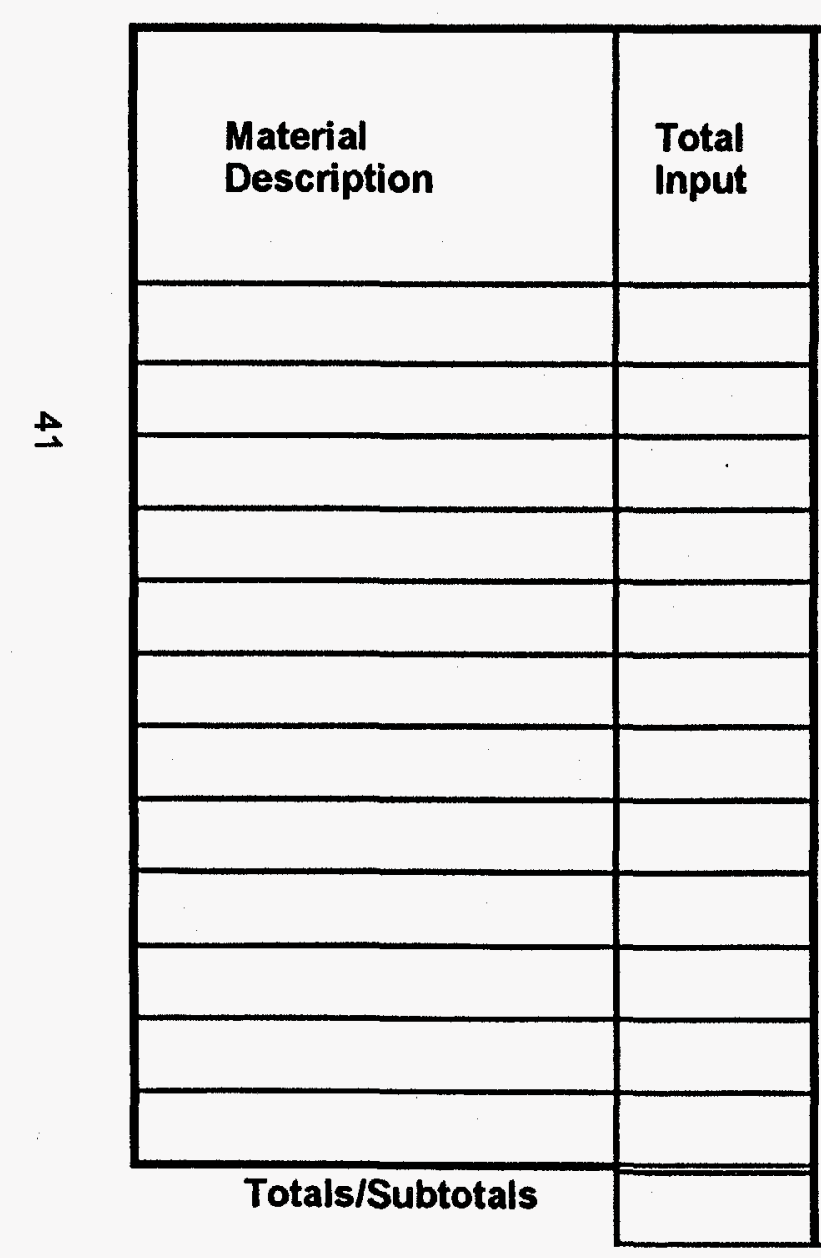
PPOA Title or PPOA ID Code(s):
Revision No.:

Revision Date:

Page of

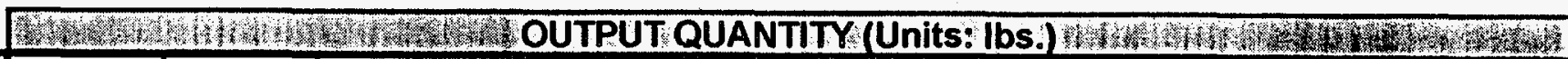

\begin{tabular}{|l|l|l|l|l|l|l|l|l|l|}
\hline Total \\
Output
\end{tabular}




\section{Worksheet 4}

A material balance is a summation of the total quantity of input material to an activity and the releases to the environment, another activity, or made into product. The purpose of Worksheet 4 is to tabulate this information and total the inputs and outputs for all streams.

1. Revision No.: List the revision number of the PPOA.

2. Revision Date: List the most recent revision date for the PPOA worksheet.

3. PPOA Title/PPOA ID Code(s): List the PPOA Title or ID Code(s) given on Worksheet 1.

4. Page ___ of ___ Indicate the page number for this worksheet and the number of pages for this worksheet.

5. From/To: Report the dates (month and year) for the time period covered. An annual period is suggested for purposes of averaging and documenting performance toward facility goals.

6. Material Description: List the material name and stock number (optional) or the output product if different than originating material.

7. Units __ : Enter the unit of measure for the input/output summary. A consistent unit of measurement is suggested. If requirements dictate mixing units, designate the units for a particular column under the Stream ID Code heading.

8. Total Input: For the material described in the far left column enter the weight of material used in the operation during the time frame specified.

9. Total Output: For the material specified in the Material Description column enter the weight of the output. This is the sum of all waste streams and any product generated. For activities where chemical reactions take place, input materials are consumed or changed to different compounds, a separate entry in the Material Description column is required to adequately define the output. In these cases, the input and output quantities will not balance for the listed material in that row.

10. Output Quantity: Use these columns to break down the total output into output categories. Refer to Worksheet 3 for the appropriate Stream ID Code for the output type. Enter the Stream ID Code at the top of the column (e.g., HZ1 for a hazardous solid waste stream), then enter the discharge amount for the material described in the Material Description column that relates to that Stream ID Code. Continue across the worksheet for all Stream ID Code(s) utilized in Worksheet 3.

11. Totals/Subtotals: Sum the Total Input, Total Output, and Output columns. Recond the sum at the bottom row of the last worksheet. Subtotals are recorded at the bottom row for other pages of the worksheet. The Total Input column should equal the Total Output column unless there is system accumulation. The Total Output column should also be the sum of all the Stream ID Code output streams.

\section{Stream ID Codes:}

\begin{tabular}{|l|c|c|}
\hline Designator & Style 1 & Style 3 \\
\hline & & \\
\hline Decontaminated/Reclamation & $\mathrm{DR}$ & $\mathrm{DR}$ \\
\hline Hazardous & $\mathrm{HZ}$ & \\
\hline Nonhazardous & $\mathrm{NH}$ & $\mathrm{NH}$ \\
\hline Other & $\mathrm{OT}$ & $\mathrm{OT}$ \\
\hline Hazardous, RCRA & & $\mathrm{HR}$ \\
\hline Hazandous, Non-RCRA & & $\mathrm{HN}$ \\
\hline Toxic, TSCA & & $\mathrm{TS}$ \\
\hline High Level & & $\mathrm{HL}$ \\
\hline Transuranic, TRU & & $\mathrm{TU}$ \\
\hline TRU, Mixed & & $\mathrm{TM}$ \\
\hline Low Level & & $\mathrm{LL}$ \\
\hline Low Level, Mixed & & $\mathrm{LM}$ \\
\hline Other, Radioactive & & $\mathrm{OR}$ \\
\hline Recycled & $\mathrm{RC}$ & $\mathrm{RC}$ \\
\hline Reused & $\mathrm{RU}$ & $\mathrm{RU}$ \\
\hline Solid Stream =1, Liquid Stream $=2$, Air Stream $=\mathbf{3}$
\end{tabular}

Style refers to the version of Worksheet 3 used. 
Womsted

Level III

\section{Pollution Prevention Opportunity Assessment}

Energy Usage Summary
Revision No.:

Revision Date:

Page: 1

Time Frame

From:

To:

\section{PPOA Title:}

\begin{tabular}{|c|c|c|c|c|c|c|c|c|}
\hline \multirow[b]{2}{*}{ Equipment } & & \multicolumn{7}{|c|}{ 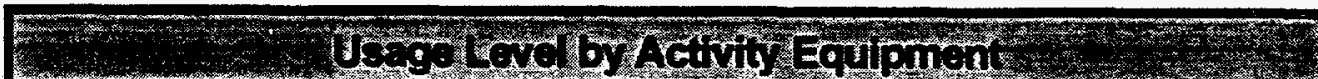 } \\
\hline & $\begin{array}{l}\text { Estimated } \\
\text { Efficiency }\end{array}$ & $\begin{array}{l}\begin{array}{c}\text { Energy } \\
\text { Resource }\end{array} \\
\text { Type: } \\
\text { U/M: }\end{array}$ & $\begin{array}{l}\begin{array}{c}\text { Energy } \\
\text { Resource }\end{array} \\
\text { Type: } \\
\text { U/M: }\end{array}$ & $\begin{array}{l}\begin{array}{c}\text { Energy } \\
\text { Resource }\end{array} \\
\text { Type: } \\
\text { U/M: }\end{array}$ & $\begin{array}{l}\begin{array}{c}\text { Energy } \\
\text { Resource }\end{array} \\
\text { Type: } \\
\text { U/M: }\end{array}$ & $\begin{array}{l}\begin{array}{c}\text { Energy } \\
\text { Resource }\end{array} \\
\text { Type: } \\
\text { U/M: }\end{array}$ & $\begin{array}{l}\text { Energy } \\
\text { Resource }\end{array}$ & $\begin{array}{l}\text { Energy } \\
\text { Resource } \\
\text { Type: } \\
\text { U/M: }\end{array}$ \\
\hline & & & & & & & & \\
\hline & & & & & & & & \\
\hline & & & & & & & & \\
\hline & & & & & & & & \\
\hline & & & & & & & & \\
\hline & & & & & & & & \\
\hline & & & & & & & & \\
\hline & & & & & & & & \\
\hline & & & & & & & & \\
\hline & & & & & & & & \\
\hline & & & & & & & & \\
\hline & & & & & & & & \\
\hline & $\begin{array}{l}\text { y Usages - } \\
\text { Totals: }\end{array}$ & & & & & & & \\
\hline
\end{tabular}




\section{Workstere}

Level III

\section{Pollution Prevention Opportunity Assessment Energy Usage Summary Help}

The energy summary is a tabulation of the total quantity of energy utilized by the activity and related equipment. The purpose of Worksheet $4 \mathrm{E}$ is to identify energy resource usage types and document the usage level by equipment.

1. Revision No.: List the revision number of the PPOA.

2. Revision Date: List the most recent revision date for the PPOA worksheet.

3. PPOA Title/PPOA ID Code(s): List the PPOA Title or ID Code(s) given on Worksheet 1.

4. Page of pages for this worksheet. : Indicate the page number for this worksheet and the number of

5. From/To: Report the dates (month and year) for the time period covered. An annual period is suggested for purposes of averaging and documenting performance toward facility goals.

6. Equipment: List the equipment name in the column heading under "Equipment". In the remainder of the row, for the energy resource specified in the Energy Resource column, enter the amount of the resource that is attributable to the listed piece of equipment.

7. Estimated Efficiency: For the listed Equipment described in the far left column enter the estimated efficiency in percentage, if known, or by indicating, high, medium or low.

8. Energy Resource: List some of the major energy resources and types. Additional spaces are provided for more activity specific needs. The "Type" blank should be filled in with the specific energy usage type. Examples of some energy resources and some specific types are as follows: (Use the normenclature - "standard" when unable to determine the specific type.)

\section{Enerov Resource: Electricity}

Types - coal generated, gas generated, hydroelectric, nuclear (fission), or geothermal (steam)

\section{Enerov Resource: Fossil Fuels}

Types - gasoline, butane, propane, coal, fuel oils, diesel fuel, or natural gas

\section{Eneray Resource: Water}

Types - electricity, natural gas, propane, or coal

\section{Energy Resources: Gas}

Types - butane, propane, generated methane, or natural gas 


\section{Pollution Prevention Opportunity Assessment \\ Material Cost}

Level III

PPOA ID Code:

PPOA Title:

Revision No.:

Revision Date:

Page:

INPUT MATERIAL COSTS

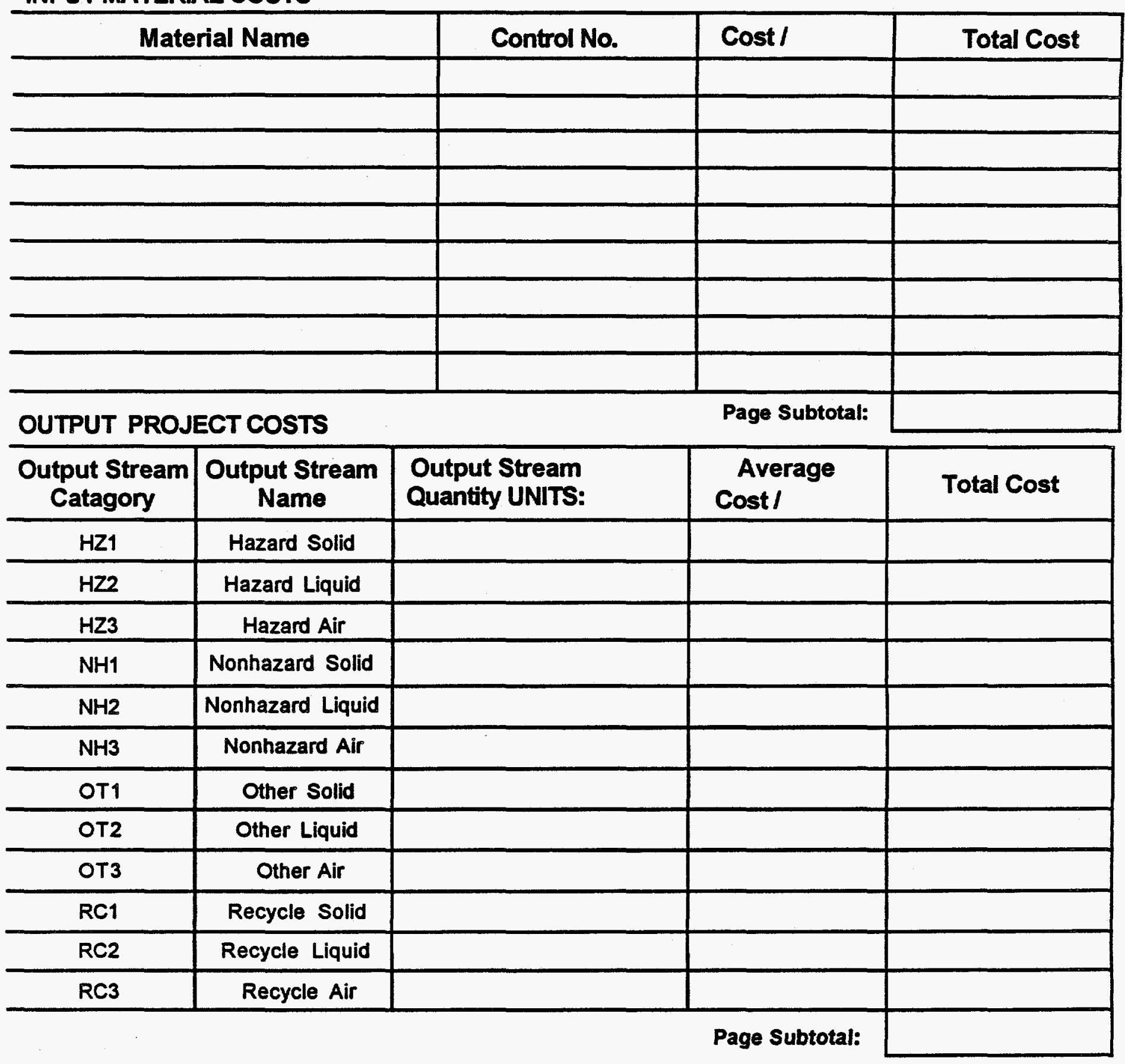

Page Total - Input Material and Output/Disposal Cost: 


\section{Worksheet 5 :}

Style 1

Level III

\title{
Pollution Prevention Opportunity Assessment
}

\author{
Material Cost
}

\section{Help}

Worksheet 5 details the cost of the PPOA input materials (use the quantities from Worksheet 4) and the cost of disposal for these materials. The material cost may be obtained from Purchasing or Stores. The cost of disposal may be obtained from Waste Management or Accounting. Annual Cost is calculated from the amount of material placed in the process or from the amount of disposed material, multiplied by the cost per unit.

1. Revision No: List the revision number for this worksheet.

2. Revision Date: List the most recent revision date for this worksheet.

3. Page of : Indicate the number of this page and the total number of pages for this worksheet.

4. PPOA Title or PPOA ID Code(s): List the PPOA Title or PPOA ID Code(s) given on Worksheet 1.

5. Input Material Costs: List the material, stock number (if applicable), cost per unit (\$/lb., \$/gal, etc.), and the annual cost for this activity.

6. Output Project Costs: List the material or output stream, waste stream category, (e.g., hazardous liquid), stock number if applicable, the cost per unit (\$/lb., $\$ / g a l$, etc.), and annual cost.

7. Totals / Subtotals: Record the sum of the annual costs for the materials or waste streams listed. There will be a total for both the input material cost and waste disposal cost. 


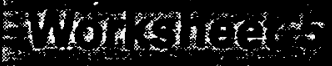

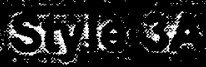

Level III

PPOA ID Code:

\section{Pollution Prevention Opportunity Assessment \\ Material Cost}

PPOA Tite:
Revision No.:

Revision Date:

Page: $1 \mathrm{~A}$

INPUT MATERLAL COST

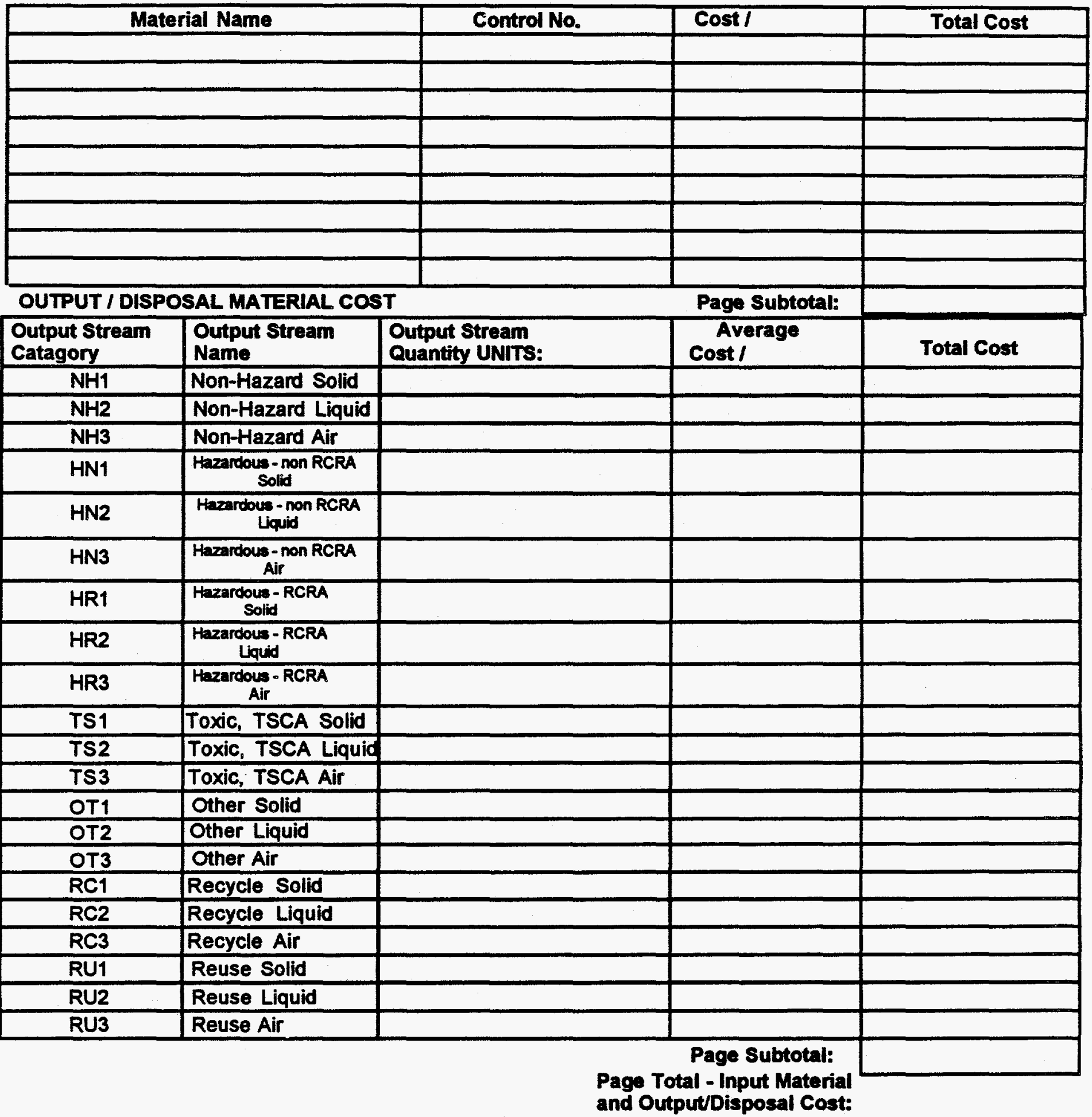

Found Set Total - Input Material and Output/Disposal Material Cost: 


\section{Whotherats}

Sinto:

Level III

\section{Pollution Prevention Opportunity Assessment \\ Material Cost}

\section{Help}

Worksheet 5 details the cost of the PPOA input materials (use the quantities from Worksheet 4) and the cost of disposal for these materials. The material cost may be obtained from Purchasing or Stores. The cost of disposal may be obtained from Waste Management or Accounting. Annual Cost is calculated from the amount of material placed in the process or from the amount of disposed material, multiplied by the cost per unit.

1. Revision No.: List the revision number for this worksheet.

2. Revision Date: List the most recent revision date for this worksheet.

3. Page___ of ___ Indicate the number of this page and the total number of pages for this worksheet.

4. PPOA Title or PPOA ID Code(s): List the PPOA Title or PPOA ID Code(s) given on Worksheet 1.

5. Input Material Cost: List the material, stock number (if applicable), cost per unit (\$/b., \$/gal, etc.), and the annual cost for this activity.

6. Waste Disposal Cost: List the material or waste stream, waste stream category, (e.g., hazardous liquid), stock number if applicable, the cost per unit (\$/b., $\$ / g a l$, etc.), and annual cost.

7. Totals / Subtotals: Record the sum of the annual costs for the materials or waste streams listed. There will be a total for both the input material cost and waste disposal cost. 


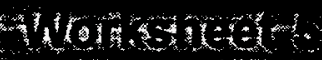

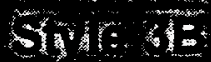

Level III

PPOA ID Code:

\section{Pollution Prevention Opportunity Assessment \\ Material Cost}

Revision No.:

Revision Date:

Page:

PPOA TItE:

INPUT MATERIAL COST

\begin{tabular}{|l|l|l|l|}
\hline Material Name & Control No. & Cost I & Total Cost \\
\hline & & & \\
\hline & & & \\
\hline & & & \\
\hline & & & \\
\hline & & & \\
\hline & & & \\
\hline
\end{tabular}

\section{OUTPUT / DISPOSAL MATERIAL COST}

\begin{tabular}{|c|l|}
\hline $\begin{array}{c}\text { Output Stream } \\
\text { Catagory }\end{array}$ & \multicolumn{1}{|c|}{$\begin{array}{c}\text { Output Stream } \\
\text { Name }\end{array}$} \\
\hline LL2 & Low Level Solid \\
\hline LL3 & Low Level Liquid \\
\hline LM1 & Low Level Air \\
\hline LM2 & Lowel, Moved, Moved Liquid \\
\hline LM3 & Low Level, Moxed Air \\
\hline TM1 & TRU, Mixed Solid \\
\hline TM2 & TRU, Mixed Liquid \\
\hline TM3 & TRU, Mixed Air \\
\hline TU1 & Transuranic, (TRU) Solid \\
\hline TU2 & Transuranic, (TRU) Liquid \\
\hline TU3 & Traneurnenc, (TRU) Ar \\
\hline HL1 & High Level Solid \\
\hline HL2 & High Level Liquid \\
\hline HL3 & High Level Air \\
\hline OR1 & Other, Rad Solid \\
\hline OR2 & Other, Rad Liquid \\
\hline OR3 & Other, Rad Air \\
\hline
\end{tabular}

\section{Output Stream Quantity UNIT:}

\section{Average}

Cost 1

Total Cost

Page Subtotal:

Page Total - Input Material and Output/Disposal Cost:

Found Set Total - Input Material and

Output/Disposal Material Cost: 
Level III

\section{Pollution Prevention Opportunity Assessment \\ Material Cost}

\section{Help}

Worksheet 5 details the cost of the PPOA input materials (use the quantities from Worksheet 4) and the cost of disposal for these materials. The material cost may be obtained from Purchasing or Stores. The cost of disposal may be obtained from Waste Management or Accounting. Annual Cost is calculated from the amount of material placed in the process or from the amount of disposed material, multiplied by the cost per unit.

1. Revision No.: List the revision number for this worksheet.

2. Revision Date: List the most recent revision date for this worksheet.

3. Page____ of ____ Indicate the number of this page and the total number of pages for this worksheet.

4. PPOA Title or PPOA ID Code(s): List the PPOA Title or PPOA ID Code(s) given on Worksheet 1.

5. Input Material Cost: List the material, stock number (if applicable), cost per unit $(\$ / \mathrm{b} ., \$ / g a l$, etc.), and the annual cost for this activity.

6. Waste Disposal Cost: List the material or waste stream, waste stream category, (e.g., hazardous liquid), stock number if applicable, the cost per unit (\$/b., $\$ / g a l$, etc.), and annual cost.

7. Totals / Subtotals: Record the sum of the annual costs for the materials or waste streams listed. There will be a total for both the input material cost and waste disposal cost. 


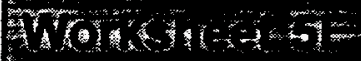

Level III
Pollution Prevention Opportunity Assessment

Energy Cost
Revision No.:

Revision Date:

Page:

PPOAID Code:

PPOATitle:

Input Cost:

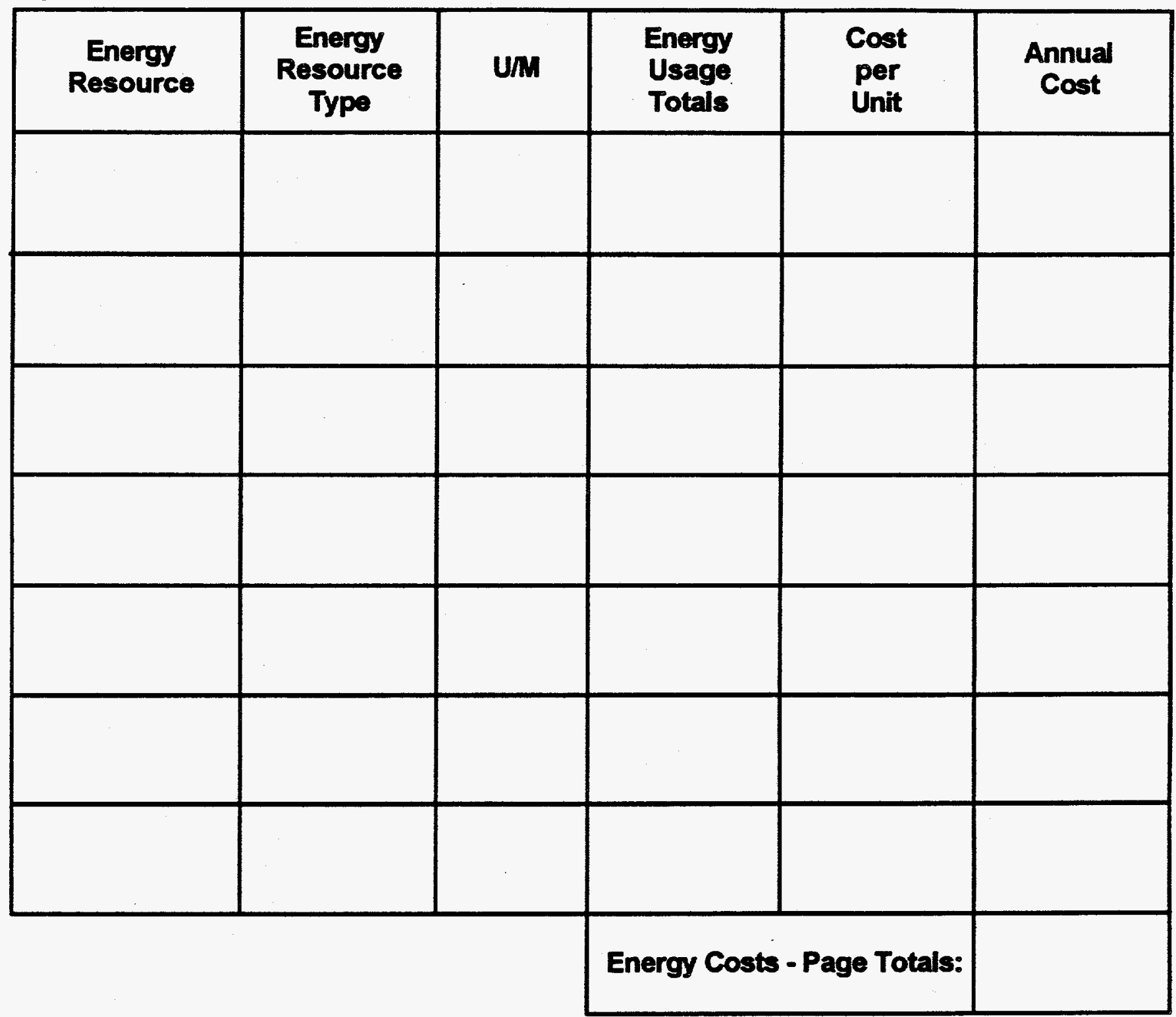

Found Set Total - Energy Costs: 
WoHAfice

Level III

\section{Pollution Prevention \\ Opportunity Assessment \\ Energy Cost \\ Help}

Worksheet 5E details the cost of the PPOA energy resources (use the quantities from Worksheet 4E) for equipment identified as utilizing energy resouces by the PPOA activity. The "Cost per Unit" may be obtained from the location's plantfacility organization or from the utility companies supplying the energy resource. The "Annual Cost" is calculated by multiplying the "Energy Usage Total" by the "Cost per Unit".

To move from field to field, either use mouse and click desired field, or use TAB key.

1. Revision No.: List the revision number for this worksheet. \{Original issue $=0$.

2. Revision Date: Automatically updated any time a change is made to a record.

3. PPOA Title: List the PPOA title selected by the team.

4. PPOA ID Code(s): List the PPOA ID Code(s) selected by the team.

5. Energy Resource: List some of the major energy resources and types. Additional spaces are provided for more activity specific needs. The "Type" blank should be filled in with the specific energy usage type. Examples of some energy resources and some specific types are as follows: (Use the nomenclature - "standard" when unable to determine the specific type.)

Enerov Resource: Electricity

Types - coal generated, gas generated, hydroelectric, nuclear (fission), or geothermal (steam)

\section{Eneray Resource: Fossil Fuels}

Types - gasoline, butane, propane, coal, fuel oils, diesel fuel, or natural gas

\section{Energy Resource: Water}

Types - electricity, natural gas, propane, or coal

\section{Energy Resources: Gas}

Types - butane, propane, generated methane, or natural gas

6. U/M: The unit of measure used by the location's plantfacility organization or by the energy resource utility company.

7. Cost per Unit: The cost per unit of measure as quoted by the location's plant/facility organization or by th utility company(ies).

8. Annual Cost: The result of multiplying the "Energy Usage Total" column by the "Cost per Unit". 


\section{MAJOR ACTIVITY TYPE}

Environmental Restoration

Laboratory

Maintenance

Manufacturing

Nuclear Facility Operations

Office

Service

Waste Management

SPECIFIC ACTIVITY TYPE

\section{Abatement}

Activation

Baking

Burn-In

Cafeteria

Calibration

W

Caulking

Cleaning

Coating

Concrete Scabbling

Construction

Curing

Cushioning

Deactivation

Decommissioning

Decontamination

Demineralization

Demolition

Depotting

Dismantlement

Disposal

Disposition

Drilling

Encapsulation

Energy Generation

Excavations
Activity Lists

SPECIFIC ACTIVITY TYPE (con't)

Field Analysis

Fire Protection

Heat Treating

Inspection

Joining

Labeling

Laboratory, Biological

Laboratory, Chemical

Laboratory, Electronics

Laboratory, Environmental

Laboratory, Mechanics

Laboratory, Medical

Laboratory, Metallurgy

Laboratory, Organic

Laboratory, Physics

Laboratory, Radiological

Laundry Operations

Machining

Maintenance, Building

Maintenance, Equipment

Maintenance, Grounds

Maintenance, Utilities

Maintenance, Vehicle

Medical

Metrology

Mixing

Molding

Monitoring

Nuclear, Accelerator

Nuclear, Beam Alignment

Nuclear, Critical Experiments

Nuclear, Hot Cell Operations

Nuclear, Material Processing

Nuclear, Neutron Diffraction

Nuclear, Neutron Scattering

Nuclear, Reactor Operations

\section{SPECIFIC ACTIVITY TYPE (con't)}

Nuclear, Shielding Operations

Nuclear, Target Production/Maintenance

Packaging

Painting

Photographic Services

Plating \& Surface Finishing

Printing

Purchasing

Radiological Surveys

Recovery

Recycling

Relamping

Remediation

Removal

Repair

Robotics

Salvage

Sampling \& Characterization

Sand Blasting

Security

Segmenting

Shipping

Shut Down

Soil Washing

Soldering

Spill Cleanup

Staking

Surveillance \& Maintenance

Transportation

Treating Leather

Waste Management, Disposal

Waste Management, Handling

Waste Management, Storage

Waste Management, Treatment

Welding 
MAJOR WASTE TYPE

Hazardous Waste

High Level Waste

Low Level Mixed Waste

Low Level Waste

Sanitary Waste

Transuranic Mixed Waste

Transuranic Waste
SPECIFIC WASTE TYPE

Abrasive

Acid

Aerosol Cans

Air Emissions

Antifreeze

Aqueous

Asbestos

Asphalt

Batteries

Cafeteria Refuse

Cardboard

Caustic

Chemicals

Circuit Boards

Cleaning Supplies

Compressed Gas Cylinders

Concrete

Construction Debri

\section{Containers}

Core Samples

Cyanide

Drilling Fluids \& Muds

Equipment

Explosives

Fertilizer

Filters

Fluorescent Lamps

Glass

Glove Bags

Grease

Inorganic Solid

Lab Packs

Laundry
SPECIFIC WASTE TYPE (con't)

Lead

Leather

Medical, Infectious

Mercury

Metal Debri

Metal, Precious

Office Trash

Oil

Oxidizers

Packaging Materials

Paint

Paper

Personal Protective Equipment

Petroleum

Plastic

Plutonium

Polychlorinated Biphenyls, PCBs

Polymers

Rubber

Sanitary Sewer

Sludge

Soil

Solid Wasto

Solvents

Textiles

Toner Cartridges

Trees, Limbs \& Brush

Uranium

Wastewater

Wood 